\title{
New Acetylide Migration and Oxygen Transfer Reactions in Ruthenium Complexes Containing an Acetyl-Substituted Cp Ligand
}

\author{
J en-Fuh Liu, Shou-Ling Huang, Ying-Chih Lin,* Yi-Hung Liu, and Yu Wang \\ Department of Chemistry, National Taiwan University, Taipe, Taiwan 106, Republic of China
}

Received October 12, 2001

\begin{abstract}
Formation of $\left[\eta^{5}: \eta^{1}-\mathrm{C}_{5} \mathrm{H}_{4} \mathrm{C}\left(\mathrm{CH}_{3}\right)=\mathrm{C}(\mathrm{Ph}) \mathrm{C}(\mathrm{O})\right]\left(\mathrm{PPh}_{3}\right)_{2} \mathrm{Ru}(3 \mathrm{a})$ from the reaction of $\left(\eta^{5}-\mathrm{C}_{5} \mathrm{H}_{4}-\right.$ $\left.\mathrm{COCH}_{3}\right)\left(\mathrm{PPh}_{3}\right)_{2} \mathrm{RuCl}(\mathbf{2 a})$ with $\mathrm{PhC} \equiv \mathrm{CH}$ proceeds via the vinylidene intermediate $\left[\left(\eta^{5}-\mathrm{C}_{5} \mathrm{H}_{4}-\right.\right.$ $\left.\left.\mathrm{COCH}_{3}\right)\left(\mathrm{PPh}_{3}\right)_{2} \mathrm{Ru}=\mathrm{C}=\mathrm{CHPh}\right] \mathrm{Cl}(\mathbf{4 a})$. In this reaction the oxygen atom of the pendant acetyl group in the cyclopentadienyl ligand of $\mathbf{4 a}$ is transferred to $\mathrm{C}_{\alpha}$ of the vinylidene ligand, and this transfer is accompanied by formation of a $\mathrm{C}=\mathrm{C}$ bond, giving 3a. Treatment of $\mathbf{2 a}$ with $\mathrm{LiC} \equiv \mathrm{CPh}$ affords $\left(\eta^{5}-\mathrm{C}_{5} \mathrm{H}_{4} \mathrm{C}(\mathrm{CCPh})(\mathrm{OH}) \mathrm{CH}_{3}\right)\left(\mathrm{PPh}_{3}\right)_{2} \mathrm{RuCl}(\mathbf{6 a})$, and passing $\mathbf{6 a}$ through a column packed with alumina also gives 3a. The latter transformation involves a new migration of an acetylide group from exocyclic $\mathrm{C}_{\alpha}$ of a substituted cyclopentadienyl ligand to the Ru center followed by the same oxygen transfer process. The metal acetylide $\left(\eta^{5}-\right.$ $\left.\mathrm{C}_{5} \mathrm{H}_{4} \mathrm{COCH}_{3}\right)(\mathrm{BINAP}) \mathrm{RuC} \equiv \mathrm{CPh}(\mathbf{5 c})$, resulting from the same migration but with no oxygen transfer, is isolated when two $\mathrm{PPh}_{3}$ ligands are replaced by BINAP. The structures of complexes $\mathbf{3} \mathbf{a}$ and $\mathbf{6 b}$, a chirophos analogue of $\mathbf{6} \mathbf{a}$, have been determined by X-ray diffraction analysis.
\end{abstract}

\section{Introduction}

We have previously reported the deprotonation reaction of (cyclopentadienyl)ruthenium vinylidene complexes, ${ }^{1}$ generating a rare class of cyclopropenyl complexes. The electrophilic $C_{\alpha}$ of the vinylideneligand facilitates cyclization via a facile nucleophilic addition of the nei ghboring carbanion after deprotonation to afford the product. It has been demonstrated that nucleophilic addition of a hydroxyl group to $\mathrm{C}_{\alpha}$ of a vinylidene complex provides access to an oxacarbene, and this has been employed in the cycloisomerization transformation of terminal alkynyl alcohol in efficient syntheses of antiviral nucleosides, polycyclic ethers, and oligosaccharides. ${ }^{2}$ Since the chemistry of substituted $\pi$-bonded cyclopentadienyl ${ }^{3}$ organometallic complexes continues to be of great interest due to their potential importance in the development of carbon-carbon bond formations ${ }^{4}$ and their uses in the syntheses of unsaturated organic species and organometallic polymers, ${ }^{5}$ we prepared an

(1) (a) Ting, P. C.; Lin, Y. C.; Lee, G. H.; Cheng, M. C.; Wang, Y. J . Am. Chem. Soc. 1996, 118, 6433. (b) Lo, Y. H.; Lin, Y. C.; Lee, G. H.; Wang, Y. Organometallics 1999, 18, 982.

(2) McDonald, F. E. Chem. Eur. J . 1999, 5, 3103.

(3) (a) Chu, H. S.; Lau, C. P.; Wong, K. Y.; Wong, W. T. Organome tallics 1998, 17, 2768. (b) Philippopoulos, A. I.; Hadjiliadis, N.; Hart, C. E.; Donnadieu, B.; M CGowan, P. C.; Poil lblanc, R. Inorg. Chem. 1997, 36, 1842. (c) Achar, S.; Immoos, C. E.; Hill, M. G.; Catalano, V.J I Inorg. Chem. 1997, 36, 2314. (d) Broussier, R.; Laly, M.; Perron, P.; Gautheron, B.; M'Koyan, S.; Kalck, P.; Wheatley, N. J . Organomet. Chem. 1999, 574, 267. (e) Christie, S. D. R.; Man, K. W.; Whitby, R. J .; Slawin, A. M. Z. Organometallics 1999, 18, 348. (f) Gallagher, M.; Dougherty, P.; Tanner, P. S.; Barbini, D. C.; Schulte, J .; J ones, W. E., J r. Inorg. Chem. 1999, 38, 2953. (g) Collin, J.; Giuseppone, N.; Van de Weghe, P. Coord. Chem. Rev. 1998, 178-180 (Part 1), 117. (h) Mu, Y.; Piers, W. E.; MacQuarrie, D. C.; Zaworotko, M. J . Can. J . Chem. 1996, 74 1696. (i) Trouve, G.; Laske, D. A.; Meetsma, A.; Teuben, J. H. J . Organomet. Chem. 1996, 511, 255. (j) Spence, R. E. V. H.; Piers, W. E. Organometallics 1995, 14, 4617. (k) Horton, A. D. Organometallics 1992, 11, 3271.

\section{Scheme 1}

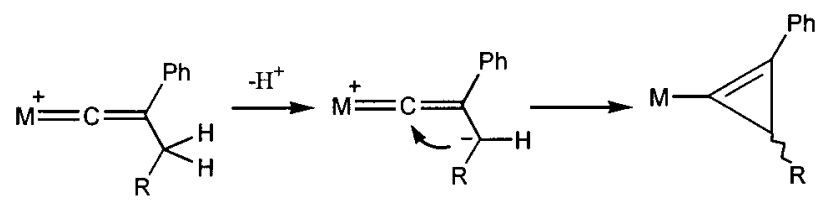

(acetylcyclopentadienyl)ruthenium chloride complex ${ }^{6}$ and carried out the reaction of this chloride with phenylacetylene in order to get a similar cycl opropenyl complex. Surprisingly, in this reaction a new type of oxygen transfer process is observed. Herein we report this new reaction where the oxygen atom transfers from the pendant acetyl group of the acetylcyclopentadienyl ligand to the vinylidene ligand. Such a transfer is followed by a carbon-carbon bond formation between the vinylidene and the pendant unit of the acetylcyclopentadienyl ligands to yield a new metal acyl complex. Also reported is a novel acetylide migration reaction found during our investigation into the mechanism of the oxygen transfer reaction.

(4) (a) Ferrocenes; Hayashi, T., Togni. A., Eds.; VCH: Weinheim, Germany, 1995. (b) Transition Metals for Organic Synthesis: Beller, M., Bolm, C., Eds.; Wiley-VCH: Weinheim, Germany, 1998. (c) Spindler, F.; Pugin, B.; J alett, H. P.; Buser, H. P.; Pittelkow, U.; Blaser, H. U. Chem. Ind. 1996, 68, 153. (d) Blaser, H.-U.; Spindler, F. In Comprehensive Asymmetric Catalysis; J acobsen. E. N., Pfaltz, A., Yamamoto, I.-I., Eds.; Springer: Berlin, 1999; Vol. 3, p 1427. (e) Imwinkelried, R. Chimia 1997, 51, 300. (f) Lee, D.-H.; Patel, B. P.; Clot, E.; Eisenstein, O.; Crabtree, R. H. Chem. Commun. 1999, 297.

(5) Nguyen, P.; Gómez-Elipe, P.; Manners, I. Chem. Rev. 1999, 99, 1515.

(6) (a) Gassman, P. G.; Winter, C. H. J . Am. Chem. Soc. 1988, 110, 6130. (b) Watanabe, M.; I wamoto, T.; Sano, H.; Kubo, A.; Motoyama, I. J . Organomet. Chem. 1992, 441, 309. (c) Suzuki, H.; Kakigano, T.; Fukui, H.; Tanaka, M.; Moro-oka, Y.J . Organomet. Chem. 1994, 473, 295. 
Scheme 2
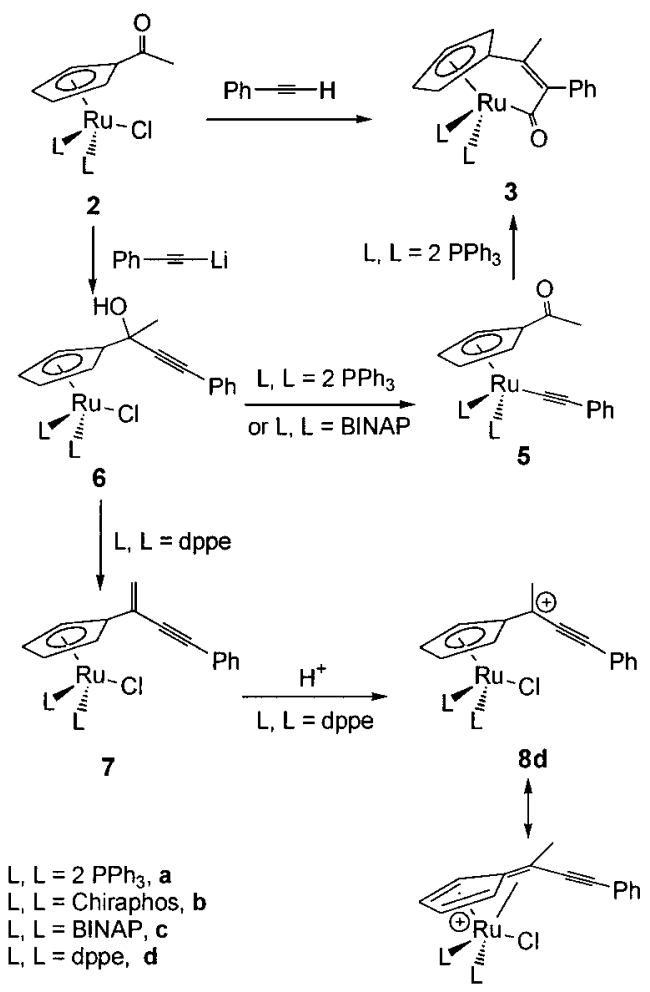

$L, L=2 \mathrm{PPh}_{3}, \mathrm{a}$

$L, L=$ Chiraphos,$b$

$\mathrm{L}, \mathrm{L}=\mathrm{BINAP}, \mathrm{c}$

$L, L=$ dppe, $\mathbf{d}$

\section{Results and Discussion}

Preparation of Acetylcyclopentadienyl Complexes. The literature method ${ }^{7}$ for the preparation of a ruthenium chloride complex with an acetylcycl opentadienyl ligand is modified to give the desired product in a higher yield. Hydrated ruthenium trichloride, $\mathrm{RuCl}_{3}$. $\mathrm{xH}_{2} \mathrm{O}$, in ethanol is added to a heated solution of acetylcyclopentadiene ${ }^{8}$ and $\mathrm{PPh}_{3}$ in ethanol/ether (4:1), and the solution turns red in about $2 \mathrm{~h}$. The deep red product obtained from this solution is identified as $\left(\eta^{5}-\mathrm{C}_{5} \mathrm{H}_{4}-\right.$ $\left.\mathrm{COCH}_{3}\right)\left(\mathrm{PPh}_{3}\right)_{2} \mathrm{RuCl}$ (2a). Complex $2 \mathbf{a}$ is soluble in $\mathrm{CHCl}_{3}, \mathrm{CH}_{2} \mathrm{Cl}_{2}$, and acetone and insoluble in $\mathrm{CH}_{3} \mathrm{OH}$, ether, and hexane. ${ }^{1} \mathrm{H}$ and ${ }^{31} \mathrm{P}$ NMR data of $\mathbf{2 a}$ are consistent with the literature values. ${ }^{7}$ In addition, in the ${ }^{13} \mathrm{C}$ N M R spectrum of $\mathbf{2 a}$ the resonance attributable to the carbonyl carbon appears at $\delta$ 197.1. Similar complexes $\left(\eta^{5}-\mathrm{C}_{5} \mathrm{H}_{4} \mathrm{COCH}_{3}\right)(\mathrm{L}-\mathrm{L}) \mathrm{RuCl}(\mathrm{L}-\mathrm{L}=(2 \mathrm{~S}, 3 \mathrm{~S})$ $(-)-\mathrm{Ph}_{2} \mathrm{PCHMeCHMePPh}, \mathbf{2}$; $;-L=(R)-(+)-B I N A P$, $\mathbf{2 c}$; $L-L=d p p e, \mathbf{2 d}$ ) are prepared from the reaction of $2 \mathbf{a}$ with the corresponding bidentate phosphines under various reaction conditions. The ${ }^{13} \mathrm{C}$ NMR resonances of the acyl carbon in these complexes all appear at $\delta$ $197 \pm 1$. The chemical shifts of two ${ }^{31}$ P NMR resonances of the bidentate chiral phosphine ligands in $\mathbf{2 b}(\delta 81.11$, $68.85)$ and $\mathbf{2 c}(\delta 49.21,39.55)$ are significantly different.

Reaction of Phenylacetylene with $\mathbf{2}$. The reaction of $\mathbf{2 a}$ with $\mathrm{PhC} \equiv \mathrm{CH}$ in $\mathrm{MeOH}$ at $64^{\circ} \mathrm{C}$ for $4 \mathrm{~h}$ proceeds via a somewhat complicated and unprecedented process to afford $\left[\eta^{5}: \eta^{1}-\mathrm{C}_{5} \mathrm{H}_{4} \mathrm{C}\left(\mathrm{CH}_{3}\right)=\mathrm{C}(\mathrm{Ph}) \mathrm{C}(\mathrm{O})\right]\left(\mathrm{PPh}_{3}\right)_{2} \mathrm{Ru}$ (3a) in $86 \%$ yield (see Scheme 2 ). The ${ }^{13} \mathrm{C}$ NMR spectrum of 3a displays a triplet resonance at $\delta 247.7$ with J c-p $=$

(7) Reventos, L. B.; Alonso, A. G. J . Organomet. Chem. 1986, 309, 179

(8) (a) Grundke, G.; Hoffmann, H. M. R. J . Org. Chem. 1981, 46, 5428. (b) Hart, W. P.; Macomber, D. W.; Rausch, M. D. J . Am. Chem. Soc. 1980, 102, 1196.
$12.5 \mathrm{~Hz}$, indicating the presence of a metal acyl carbon. ${ }^{9}$ This ${ }^{13} \mathrm{C}$ resonance shifts significantly downfield from that ( $\delta$ 197.1) of the acetyl unit of $\mathbf{2 a}$. The triplet pattern resulting from coupling with two phosphine atoms is consistent with the presence of a metal acyl group. Two resonances at $\delta 168.1$ and 142.3 are assigned to two ol efinic carbon atoms of the pendant chain. The ${ }^{1} \mathrm{H}$ NMR spectrum of 3a displays a singlet resonance at $\delta 2.12$, assignable to the methyl group. From an HMBC (heteronuclear multiple bond connectivity) 2D NMR spectrum, ${ }^{10}$ long-range $\mathrm{C}-\mathrm{H}$ couplings of this methyl proton are revealed by three cross-peaks of this ${ }^{1} \mathrm{H}$ resonance, showing correlation with the ${ }^{13} \mathrm{C}$ resonances at $\delta 168.1$, 142.3, and 247.7 assignable to two ol efinic carbons and the acyl carbon, respectively. These data reveal that the methyl group remains attached in the substituted $\mathrm{Cp}$ ligand and is also bonded to the added portion derived from phenylacetylene. In the ${ }^{31} \mathrm{P}$ NMR spectrum, the singlet resonance at $\delta 49.13$ is assigned to the $\mathrm{PPh}_{3}$ ligand. Two IR absorption peaks at 1772 and $1681 \mathrm{~cm}^{-1}$ are assigned to the $\mathrm{C}=\mathrm{O}$ and $\mathrm{C}=\mathrm{C}$ stretching, respectively. We have carried out reactions of phenylacetylene with the similar complexes $\mathbf{2} \mathbf{b}, \mathbf{2 c}$, and $\mathbf{2 d}$, yiel ding $\mathbf{3 b}$ $(81 \%), 3 c(72 \%)$, and 3d (65\%), respectively. These reactions all give complexes of the same type. Characteristic ${ }^{13} \mathrm{C}$ resonances at $\delta 250 \pm 8$ are all observed for these complexes. All $31 \mathrm{P}$ NMR resonances of $\mathbf{3}$ shift toward a downfield region relative to those of their corresponding chloride complexes $\mathbf{2}$.

Spectroscopic data for $\mathbf{3}$ mentioned above are not sufficient for making a full assignment of the structure. Attempts were thus made to search for reaction intermediates. We noticed that, during the course of the reaction of $\mathbf{2 a}$ with $\mathrm{PhC} \equiv \mathrm{CH}$, the col or of the mixture changed from deep red to orange and then to yellow. A reaction, carried out in an oil bath at $50{ }^{\circ} \mathrm{C}$, was thus stopped in $3 \mathrm{~h}$, while the color of the mixture was orange. From the mixture, the intermediate $\mathbf{4 a}$, showing a singlet ${ }^{31} \mathrm{P}$ NMR resonance at $\delta 42.87$, was observed along with $3 a$ in a 1:1 ratio. This intermediate transformed to 3a quantitatively at the reflux temperature of $\mathrm{MeOH}$. Attempted column chromatographic separation of the mixture by using a silica gel packed column caused decomposition of the intermediate and gave only 3a. The structure of the intermediate was thus deduced spectroscopically. The ${ }^{31 P}$ NMR resonance of this intermediate at $\delta 42.87$ is nearly that of a Ru vinylidene complex. ${ }^{11}$ The ${ }^{1} \mathrm{H}$ NMR resonance at $\delta 4.74$ also resembles that of a vinylidene terminal proton. ${ }^{12}$ It is known that metal acetylide can be readily prepared from deprotonation of a metal vinylidene containing a terminal proton. We therefore carried out the reaction of $\mathbf{2 a}$ with phenylacetylene in the presence of sodium methoxide. This reaction gave $\mathbf{3 a}$ and the expected acetylide complex $\left(\eta^{5}-\mathrm{C}_{5} \mathrm{H}_{4} \mathrm{COCH}_{3}\right)\left(\mathrm{PPh}_{3}\right)_{2} \mathrm{RuC} \equiv \mathrm{CPh}$ (5a) in a 1:2 ratio. Complex $\mathbf{5 a}$ is characterized by its ${ }^{31} \mathrm{P}$ NMR spectrum, showing a singlet resonance at $\delta$ 51.85 for phosphine ligands. The FAB mass spectrum displays the parent peak at $\mathrm{m} / \mathrm{z} 692.3$, corresponding

(9) Lehmkuhl, H.; Schwickardi, R.; Mehler, G.; Krueger, C.; Goddard, R. Z. Anorg. Allg. Chem. 1991, 606, 141.

(10) Willker, W.; Leibfritz, D.; Magn. Reson. Chem. 1995, 33, 632

(11) Lomprey, J . R.; Selegue, J . P. Organometallics 1993, 12, 616.

(12) (a) Trost, B. M.; Kulawiec, R. J J J Am. Chem. Soc. 1992, 114, 5579. (b) Bruce, M. I.; Hinterding, P.; Tiekink, E. R. T. J . Organomet. Chem. 1993, 450, 209. 


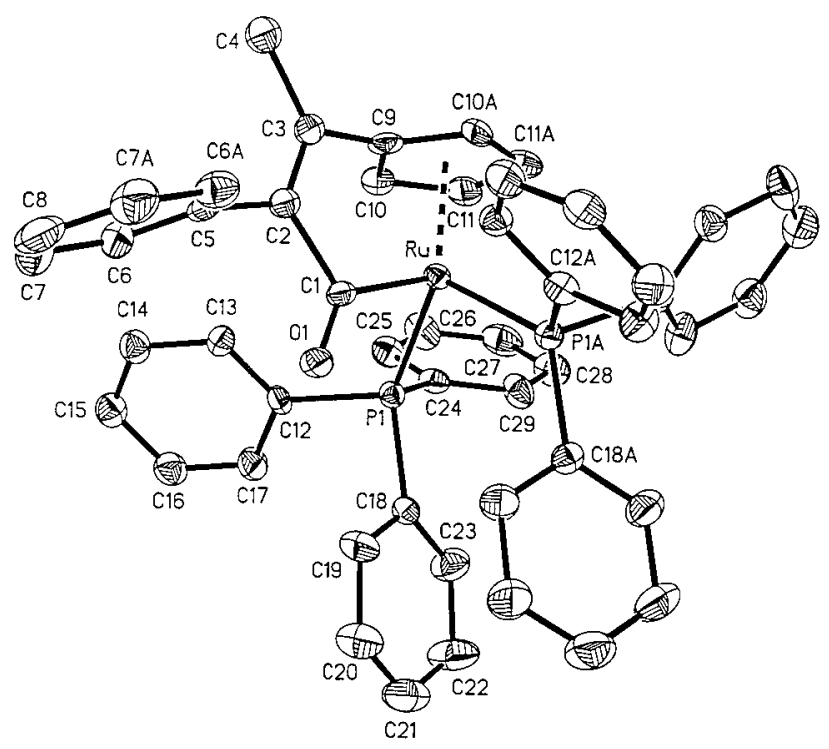

Figure 1. ORTEP drawing of $\left[\eta^{5}: \eta^{1}-\mathrm{C}_{5} \mathrm{H}_{4} \mathrm{C}\left(\mathrm{CH}_{3}\right)=\mathrm{C}(\mathrm{Ph}) \mathrm{C}\right.$ $(\mathrm{O})]\left(\mathrm{PPh}_{3}\right)_{2} \mathrm{Ru}(\mathbf{3 a})$, with thermal ellipsoids shown at the $30 \%$ probability level.

\section{Scheme 3}

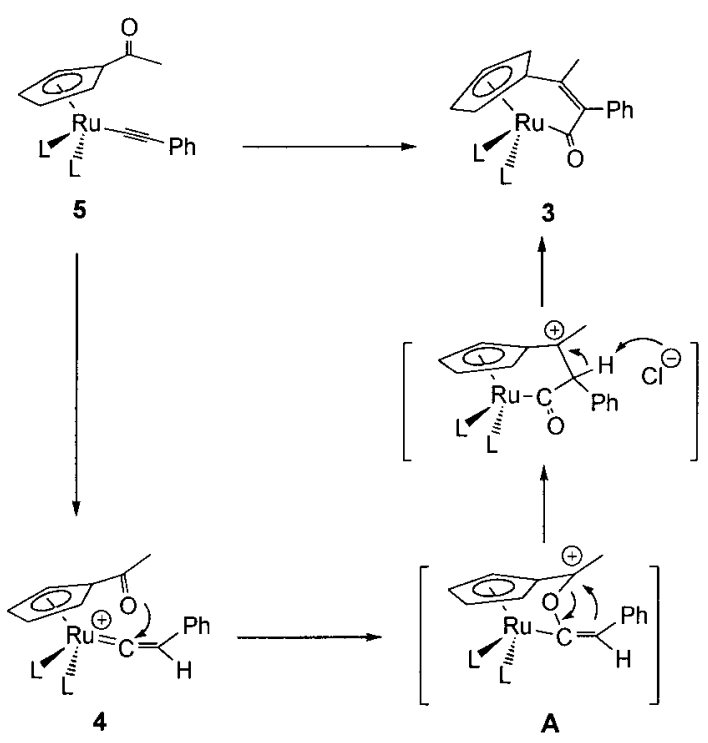

to cleavage of the acetylide and the acetyl fragments. On the basis of these data, it is reasonable to assume that the initial step of the reaction of $\mathbf{2}$ with $\mathrm{HC} \equiv \mathrm{CPh}$, in the presence of $\mathrm{MeONa}$, possibly proceeds via addition of phenylacetylene to the Ru metal center followed by deprotonation to give $\mathbf{5 a}$. We therefore believe that the intermediate isolated in the absence of sodium methoxide is $\left[\left(\eta^{5}-\mathrm{C}_{5} \mathrm{H}_{4} \mathrm{COCH}_{3}\right)\left(\mathrm{PPh}_{3}\right)_{2} \mathrm{Ru}=\mathrm{C}=\mathrm{CHPh}\right] \mathrm{Cl}$ (4a), shown in Scheme 3. In the presence of acid, 5a readily turned to $\mathbf{3 a}$, possibly also via $\mathbf{4 a}$.

To establish the solid-state structure of $\mathbf{3 a}$, an X-ray diffraction study was carried out on a single crystal of 3a recrystallized from n-hexane. This complex crystallizes in the orthorhombic space group Pnma with four molecules in a unit cell. The molecule possesses a mirror plane. An ORTEP drawing is shown in Figure 1; symmetry-generated atoms are indicated with the suffix $A$, and selected bond distances and angles are listed in Table 1. The molecule of $3 a$ lies on a mirror plane with a distorted-tetrahedral metal center. The environment
Table 1. Selected Bond Distances $(\AA)$ and Angles (deg) of $\left[\eta^{5}: \eta^{1}-C_{5} H_{4} C\left(C_{3}\right)=C(P h) C(O)\right]\left(P P h_{3}\right)_{2} R u$ (3a)

\begin{tabular}{cclc}
\hline Ru-P1 & $2.3111(9)$ & $\mathrm{Ru}-\mathrm{C} 1$ & $2.009(5)$ \\
$\mathrm{C} 1-\mathrm{O} 1$ & $1.226(5)$ & $\mathrm{C} 1-\mathrm{C} 2$ & $1.556(6)$ \\
$\mathrm{C} 2-\mathrm{C3}$ & $1.339(6)$ & $\mathrm{C} 2-\mathrm{C} 5$ & $1.488(6)$ \\
$\mathrm{C} 3-\mathrm{C} 4$ & $1.506(6)$ & $\mathrm{C} 3-\mathrm{C} 9$ & $1.495(6)$ \\
$\mathrm{P} 1-\mathrm{Ru}-\mathrm{P} 1 \mathrm{~A}$ & $104.02(4)$ & $\mathrm{P} 1-\mathrm{Ru}-\mathrm{C} 1$ & $92.59(8)$ \\
$\mathrm{Ru}-\mathrm{C} 1-\mathrm{C} 2$ & $112.7(3)$ & $\mathrm{Ru}-\mathrm{C} 1-\mathrm{O} 1$ & $131.8(3)$ \\
C2-C1-O1 & $115.5(4)$ & $\mathrm{C} 1-\mathrm{C} 2-\mathrm{C} 3$ & $118.0(4)$ \\
C1-C2-C5 & $116.4(4)$ & $\mathrm{C} 3-\mathrm{C} 2-\mathrm{C} 5$ & $125.6(4)$ \\
C2-C3-C4 & $126.6(4)$ & $\mathrm{C} 2-\mathrm{C} 3-\mathrm{C} 9$ & $116.2(4)$ \\
C4-C3-C9 & $117.2(4)$ & C3-C9-C10 & $125.3(2)$
\end{tabular}

about the ruthenium metal center consists of the $\pi$-bound $\mathrm{Cp}$ ring with its pendant chain bound also to the metal through the acyl unit and two triphenylphosphine ligands. The $\mathrm{Ru}-\mathrm{C} 1$ distance of 2.009(5) $\AA$ is a normal $\mathrm{Ru}-\mathrm{C}$ single-bond distance for a metal acyl group. The C2-C3 bond length of 1.339(6) $\AA$ is typical of a $\mathrm{C}=\mathrm{C}$ double bond.

Mechanism of Oxygen Transfer. Formation of 3a can be accounted for by the mechanism depicted in Scheme 3. The reaction of $\mathbf{2 a}$ with phenylacetylene first yields the cationic vinylidene complex $\mathbf{4 a}$ with chloride as its counteranion. It is well-known that $C_{\alpha}$ of a vinylidene ligand is susceptible to nucleophilic attack, ${ }^{13}$ particularly by a nitrogen or an oxygen donor, to give a Fischer type carbene complex. This is exceptionally facile when the nucleophilic attack is assisted by an intramolecular chelation. In our system, the oxygen atom of the pendant acetyl unit in the cyclopentadienyl ligand nearby serves as a nucleophile, giving $\mathbf{A}$ (see Scheme 3). This cation is stabilized not only by delocalizing the cationic charge in the $\mathrm{Cp}$ substituent but also by a significant contribution of the electron-rich ruthenium bisphosphine group via $\eta^{6}$-complexation and possibly by a neighboring group participation of the vinyl group. Electron donation from the neighboring vinyl group to the carbenium center causes carboncarbon bond formation. Thus, the nucleophilic attack is followed by formation of a $\mathrm{C}-\mathrm{C}$ bond and subsequent deprotonation generates the product $\mathbf{3 a}$. The presence of $\mathrm{NaOMe}$ causes deprotonation of the vinylidene intermediate $\mathbf{4 a}$ to occur to give the acetylide compl ex $\mathbf{5 a}$. An oxygen atom transfer from niobium ketene to isocyanide or nitrile, yielding a niobium vinylidene complex, has been reported. ${ }^{14}$

Acetylide Addition to the Acetyl Group of the Cp Ligand. In an attempt to prepare the acetylide complex $\mathbf{5 a}$, we carried out the reaction of $\mathbf{2 a}$ with 3 equiv of $\mathrm{LiC} \equiv \mathrm{CPh}$ in $\mathrm{CH}_{2} \mathrm{Cl}_{2}$. Surprisingly, the reaction did not give the expected product but instead generated $\left(\eta^{5}-\mathrm{C}_{5} \mathrm{H}_{4} \mathrm{C}(\mathrm{CCPh})(\mathrm{OH}) \mathrm{CH}_{3}\right)\left(\mathrm{PPh}_{3}\right)_{2} \mathrm{RuCl}(6 \mathrm{a})$ in moderate yield (see Scheme 2 ) and, interestingly, the reaction in the presence of air gave a higher yield than that in the absence of air. If the reaction in $\mathrm{CH}_{2} \mathrm{Cl}_{2}$ was carried out under nitrogen, $\mathbf{6} \mathbf{a}$ and many unidentified products

(13) (a) Slugovc, C.; Mereiter, K.; Schmid, R.; Kirchner, K. Organometallics 1998, 17, 827. (b) Bianchini, C.; Casares, J. A.; Peruzzini, M.; Romerosa, A.; Zanobini, F.J . Am. Chem. Soc. 1996, 118, 4585. (c) Bianchini, C.; Peruzzini, M.; Romerosa, A.; Zanobini, F. Organome tallics 1995, 14, 3152. (d) Barrett, A. G. M.; Carpenter, N. E. Organometallics 1987, 6, 2249. (e) Quzzine, K.; Le Bozec, H.; Dixneuf, P. H. J . Organomet. Chem. 1986, 317, C25. (f) Nombel, P.; Lugan, N.; Mathieu, R. J . Organomet. Chem. 1995, 503, C22.

(14) Fermin, M. C.; Bruno, J . W. J . Am. Chem. Soc. 1993, 115, 7511. 


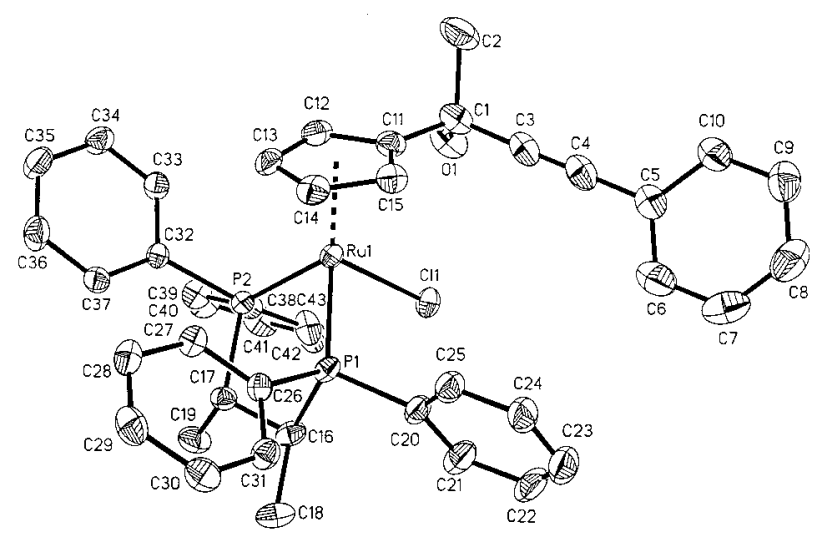

Figure 2. ORTEP drawing of $\left[\eta^{5}-\mathrm{C}_{5} \mathrm{H}_{4} \mathrm{C}(\mathrm{OH})(\mathrm{CCPh}) \mathrm{CH}_{3}\right]-$ (Chiraphos)RuCl (6b), with thermal ellipsoids shown at the $30 \%$ probability level.

were obtained. This reaction carried out in THF also gave a mixture of products. Nucleophilic addition takes place at the acetyl group, forming a propargylic al cohol group at the $\mathrm{Cp}$ ligand. Triphenylphosphine oxide was also observed as a byproduct in this reaction, and $\mathbf{6 a}$ was purified by recrystallization from a mixture of n-hexane and $\mathrm{CH}_{2} \mathrm{Cl}_{2}$. Complex $6 \mathrm{a}$ in solution is unstable and decomposes to give $\mathrm{OPPh}_{3}$ as the only identifiable product at room temperature, but a solid sample could be stored for 2 days at room temperature. In the ${ }^{31} \mathrm{P}$ NMR spectrum of $6 \mathbf{a}$ two doublet resonances at $\delta 39.0$ and 38.2 with J $\mathrm{p}-\mathrm{p}=41.4 \mathrm{~Hz}$ indicates the presence of a stereogenic center in the complex. The hydroxy proton appears as a broad singlet resonance at $\delta 6.27$ in the ${ }^{1} \mathrm{H}$ NMR spectrum, and this proton readily exchanges with deuterium in the presence of $\mathrm{D}_{2} \mathrm{O}$. These spectroscopic data as well as a crystal structure determination of a similar complex described below firmly establish the structure of the nucleophilic addition product. Complexes $\mathbf{6 b}, \mathbf{6 c}$, and $\mathbf{6 d}$ were similarly prepared from the reaction of $\mathrm{LiC} \equiv \mathrm{CPh}$ with $\mathbf{2 b}, \mathbf{2 c}$, and $\mathbf{2 d}$, respectively, in high yields. For the formation of $\mathbf{6 b}$ and $\mathbf{6 c}$ from $\mathbf{2} \mathbf{b}$ and $\mathbf{2 c}$, the diastereoselectivities are $32 \%$ and $24 \%$, respectively. The lower diastereoselectivity in this system relative to that observed in the chromium tricarbonyl system ${ }^{15}$ is not unexpected, since the chiral phosphine ligand is relatively farther away from the reactive center.

Single crystals of $\mathbf{6 b}$ were obtained by recrystallization from $n$-hexane/acetone, and the molecular structure was determined by an X-ray diffraction analysis. An ORTEP drawing is shown in Figure 2 , and selected bond distances and angles are listed in Table 2. The environment about the ruthenium metal center consists of a $\pi$-bound $\mathrm{Cp}$ ring, a chlorine atom, and a chirophos ligand. The acetylide group is bonded to the exocyclic $\mathrm{C}_{\alpha}$ of the $\mathrm{Cp}$ ligand. The pendant chain is in line with the less hindered $\mathrm{Cl}$ ligand. The $\mathrm{Ru}-\mathrm{Cl}$ distance of 2.468(1) $\AA$ is a normal $\mathrm{Ru}-\mathrm{Cl}$ single-bond distance. The C $3-C 4$ bond length of $1.211(9) \AA$ is typical of a $C \equiv C$ triple bond.

A New Acetylide Migration. Transformation of $\mathbf{6 a}$ to $3 a$ readily occurred in methanol (see Scheme 2). When $\mathbf{6 a}$ was passed through a column packed with

(15) Netz, A.; Polborn, K.; Müller, T. J . J . J . Am. Chem. Soc. 2001 $123,3441$.
Table 2. Selected Bond Distances $(\AA \AA)$ and Angles (deg) of $\left[\left(\eta^{5}-\mathrm{C}_{5} \mathrm{H}_{4} \mathrm{C}(\mathrm{CCPh})(\mathrm{OH}) \mathrm{CH}_{3}\right)\right](\mathrm{Chiraphos}) \mathrm{RuCl}(6 \mathrm{~b})$

$\begin{array}{lclr}\mathrm{Ru}-\mathrm{P} 1 & 2.2899(12) & \mathrm{Ru}-\mathrm{C} 1 & 2.4680(11) \\ \mathrm{Ru}-\mathrm{P} 2 & 2.3392(13) & \mathrm{C} 1-\mathrm{C} 11 & 1.529(9) \\ \mathrm{C} 1-\mathrm{C} 2 & 1.573(9) & \mathrm{C} 1-\mathrm{C} 3 & 1.508(9) \\ \mathrm{C} 1-\mathrm{O} 1 & 1.445(7) & \mathrm{C} 3-\mathrm{C} 4 & 1.211(9) \\ \mathrm{P} 1-\mathrm{Ru}-\mathrm{P} 2 & 82.86(4) & \mathrm{C} 3-\mathrm{C} 1-\mathrm{C} 2 & 110.0(5) \\ \mathrm{P} 1-\mathrm{Ru}-\mathrm{Cl} & 86.21(4) & \mathrm{C} 1-\mathrm{C} 3-\mathrm{C} 4 & 175.4(7) \\ \mathrm{P} 2-\mathrm{Ru}-\mathrm{Cl} & 95.12(4) & \mathrm{C} 3-\mathrm{C} 4-\mathrm{C} 5 & 178.8(6) \\ \mathrm{C} 11-\mathrm{C} 1-\mathrm{C} 2 & 109.1(6) & \mathrm{C} 1-\mathrm{C} 11-\mathrm{C} 15 & 125.8(5) \\ \mathrm{O} 1-\mathrm{C} 1-\mathrm{C} 2 & 105.4(5) & \mathrm{C} 1-\mathrm{C} 11-\mathrm{C} 12 & 125.7(5) \\ \text { O1-C1-C3 } & 110.8(5) & \mathrm{C} 15-\mathrm{C} 11-\mathrm{C} 12 & 108.3(5)\end{array}$

activated alumina or when a solution of $\mathbf{6 a}$ was stirred in the presence of $\mathrm{MeONa}$ or $\mathrm{CF}_{3} \mathrm{COOH}$, the same transformation occurred, but with much lower yield, and several intractable products were also observed. A new acetylide migration followed by the oxygen transfer mentioned above accounts for the transformation of $\mathbf{6 a}$ to $3 a$. The phenylacetylide group migrates from the exocyclic $C_{\alpha}$ of the substituted $\mathrm{Cp}$ ligand to the Ru metal center. This is followed by formation of a vinylidene complex via protonation, and then the oxygen transfer mentioned above takes place to give the final product 3a. The acetylide migration process could be assisted by dissociation of the chloride ligand in methanol. The presence of the electron-rich $\mathrm{C} \equiv \mathrm{C}$ triple bond of the propargylic group could provide yet another stabilization effect via coordination to the metal center to give the final product. Treatment of $\mathbf{6 c}$ with alumina resulted in the formation of $\mathbf{5 c}$. In this system, the vinylidene complex $\mathbf{4 c}$ could be prepared by protonation of $\mathbf{5 c}$ with $\mathrm{CF}_{3} \mathrm{COOH}$. Complex $\mathbf{4 c}$ decomposed to several unidentified products at room temperature. The oxygen transfer product was observed only as a minor product.

Interestingly, when $\mathbf{6 d}$ was subjected to chromatography on an alumina-packed column, dehydration was observed, yielding $\left[\eta^{5}-\mathrm{C}_{5} \mathrm{H}_{4} \mathrm{C}\left(=\mathrm{CH}_{2}\right) \mathrm{CCPh}\right]($ dppe) $\mathrm{RuCl}$ (7d), which was identified by spectroscopic methods. Two vinylic protons give two singlet resonances at $\delta 5.46$ and 5.59 in the ${ }^{1} \mathrm{H}$ NMR spectrum. Both correlate to the ${ }^{13} \mathrm{C}$ resonance at $\delta 118.3$ in the $2 \mathrm{D}$ NMR HMQC spectrum and to ${ }^{13} \mathrm{C}$ resonances at $\delta 94.6$ (quaternary carbon on $\mathrm{Cp}$ ) and $\delta 88.9$ and 89.2 (two acetylene carbons) in the 2D NMR HMBC spectrum. The ${ }^{31 P}$ NMR spectrum displays a singlet resonance at $\delta$ 79.66, indicating the lack of a stereogenic center. For the ferrocenyl carbocation, it is known that nucleophilic addition reactions often proceed in competition with deprotonation. ${ }^{16}$ The reaction of $\mathbf{7 d}$ with $\mathrm{CF}_{3} \mathrm{COOH}$ gave a carbenium ion product (8d) showing a two-doublet pattern at $\delta 86.46$ and $73.93(\mathrm{p}-\mathrm{p}=24.1 \mathrm{~Hz})$ in the 31P NMR spectrum. Protonation presumably occurs at the exocyclic $\mathrm{C}_{\beta},{ }^{17}$ and the restricted rotation of the exocyclic group originating from the neighboring group participation of the metal satisfactorily accounts for the planar chirality. Deprotonation of this unstable carbenium product, which does not undergo acetylide migration, in the presence of some weak nucleophiles readily gives back 7d. Reversed migration of an acetylide group

(16) Bunton, C. A.; Crawford, W.; Watts, W. E. Tetrahedron Lett. 1977, 3755

(17) (a) Pittman, C. U., J r.; Olah, G. A. J . Am. Chem. Soc. 1965, 87, 5632. (b) Olah, G. A.; Spear, R. J .; Westerman, P. W.; Denis, J .-M.J . Am. Chem. Soc. 1974, 96, 5855. 
from an Fe metal to a cyclopentadienyl ligand has been reported recently. ${ }^{18}$ In our system the migration is from the exocyclic $\mathrm{C}_{\alpha}$ of a substituted group on the $\mathrm{Cp}$ ligand to the metal.

Concluding Remarks. A new oxygen transfer reaction from an acetyl group on a substituted cyclopentadienyl ligand to a coordinated vinylidene ligand was observed in the reaction of $\mathbf{2}$ with phenylacetylene, giving 3. The reaction proceeds via addition of phenylacetylene to the ruthenium metal center to yield the vinylideneligand. The proximity of the acetyl group and the vinylidene ligand and the electrophilicity of $\mathrm{C}_{\alpha}$ of the vinylidene ligand promote such an oxygen transfer process and facilitate $\mathrm{C}=\mathrm{C}$ bond formation. In the presence of $\mathrm{MeOH}$, complex $\mathbf{6 a}$ undergoes a new acetylide migration from exocyclic $\mathrm{C}_{\alpha}$ of the substituted $\mathrm{Cp}$ ligand to the Ru metal center to yield 3 a. The migration is possibly assisted by dissociation of the chloride ligand in $6 \mathbf{a}$ and is followed by formation of a similar vinylidene complex in which oxygen transfer takes place to givethe final product 3a. Possible applications of such a reaction in synthesizing new organometallic complexes are currently under investigation.

\section{Experimental Section}

General Procedures. Unless mentioned otherwise, all mani pulations were performed under nitrogen using vacuumline, drybox, and standard Schlenk techniques. $\mathrm{CH}_{2} \mathrm{Cl}_{2}$ was distilled from $\mathrm{CaH}_{2}$, and diethyl ether and THF were distilled from $\mathrm{Na}$ /benzophenone. All other solvents and reagents were of reagent grade and were used as received. NMR spectra were recorded on Bruker AM-300WB and DMX-500 spectrometers at room temperature (unless stated otherwise). Chemical shifts are given in $\delta$ and referenced to TMS. FAB mass spectra were recorded on a J EOL SX-102A spectrometer. Acetylcyclopentadienide was prepared according to the methods reported in the literature. ${ }^{19} \mathrm{RuCl}_{3} \times \mathrm{XH}_{2} \mathrm{O}$ was purchased from Strem Chemicals. Elemental analyses and X-ray diffraction studies were carried out at the Regional Center of Analytical Instrument located at the National Taiwan University.

Preparation of $\left(\eta^{5}-\mathrm{C}_{5} \mathrm{H}_{4} \mathrm{COCH}_{3}\right)\left(\mathrm{PPh}_{3}\right)_{2} \mathrm{RuCl}$ (2a). A solution of sodium acetylcyclopentadienide $(18.0 \mathrm{~g})$ in $\mathrm{HCl}$ aqueous solution $(1.0 \mathrm{~N}, 500 \mathrm{~mL}$ ) was stirred for $30 \mathrm{~min}$. The acetylcyclopentadiene was extracted with $4 \times 25 \mathrm{~mL}$ of diethyl ether and dried over $\mathrm{MgSO}_{4}$, and the volume of the ethereal solution was reduced to ca. $10 \mathrm{~mL}$. $\mathrm{PPh}_{3}(8.0 \mathrm{~g}, 30.5 \mathrm{mmol})$ and $40 \mathrm{~mL}$ of absolute ethanol were added to the ethereal solution, and the mixture was refluxed for $10 \mathrm{~min}$; subse quently $\mathrm{RuCl}_{3} \cdot \mathrm{xH}_{2} \mathrm{O}(2.4 \mathrm{~g}$, ca. $11.6 \mathrm{mmol})$ in $20 \mathrm{~mL}$ of absolute ethanol was added to the boiling solution by syringe. The mixture was heated to reflux for another $2 \mathrm{~h}$; the red precipitates thus formed were filtered off and washed with ethanol and n-hexane $(5.1 \mathrm{~g}, 57.2 \%)$. The product can be recrystallized from $\mathrm{CH}_{2} \mathrm{Cl}_{2} / \mathrm{n}$-hexane. Spectroscopic data for $\mathbf{2 a}$ are as follows. IR $\left(\mathrm{CH}_{2} \mathrm{Cl}_{2}\right): v(\mathrm{C}=0) 1663 \mathrm{~cm}^{-1}$. ${ }^{1} \mathrm{H} \mathrm{NMR}$ $\left(\mathrm{CDCl}_{3}\right): \delta 7.44-7.07(\mathrm{~m}, 30 \mathrm{H}, \mathrm{Ph}), 5.09(\mathrm{br}, 2 \mathrm{H}, \mathrm{Cp}), 3.60$ (br, $2 \mathrm{H}, \mathrm{Cp}), 2.19\left(\mathrm{~s}, 3 \mathrm{H}, \mathrm{CH}_{3}\right) .{ }^{13} \mathrm{C} \mathrm{NMR}\left(\mathrm{CDCl}_{3}\right): \delta 197.1(\mathrm{~s}$, $\mathrm{C}=0$ ), 137.5-127.4 (m, Ph), $88.3(\mathrm{~s}, \mathrm{Cp}), 86.4(\mathrm{~s}, \mathrm{Cp}), 79.0(\mathrm{~s}$, $\mathrm{Cp}), 29.3\left(\mathrm{~s}, \mathrm{CH}_{3}\right) .{ }^{31} \mathrm{P} \mathrm{NMR}\left(\mathrm{CDCl}_{3}\right): \delta 37.96(\mathrm{~s}) . \mathrm{FAB}$ mass: $\mathrm{m} / \mathrm{z} 768.2\left(\mathrm{M}^{+}\right), 733.2\left(\mathrm{M}^{+}-\mathrm{Cl}\right), 471.0\left(\mathrm{M}^{+}-\mathrm{PPh}_{3}, \mathrm{Cl}\right)$. Anal. Calcd for $\mathrm{C}_{43} \mathrm{H}_{37} \mathrm{OP}_{2} \mathrm{RuCl}$ : C, 67.23; $\mathrm{H}, 4.86$, Found: C, 67.40; $\mathrm{H}, 4.72$.

Preparation of $\mathbf{2 b}, \mathbf{2 c}$, and $\mathbf{2 d}$. Preparation of $\mathbf{2 b}, \mathbf{2 c}$, and $\mathbf{2 d}$ from the reactions of $\mathbf{2 a}$ with corresponding free phosphine

(18) Liu, L. K.; Chang, K. Y.; Wen, Y. S. J . Chem. Soc., Dalton Trans. 1998, 1, 741 .

(19) Rogers, R. D.; Atwood, J . L.; Rausch, M. D.; Macomber, D. W.; Hart, W. P. J . Organomet. Chem. 1982, 238, 79. ligands followed the procedure given in the literature. For example, complex $\mathbf{2} \mathbf{b}$ was obtained from a thermal reaction of $2 \mathrm{a}$ with Chiraphos in benzene for $4 \mathrm{~h}$ and was purified by recrystallization from n-hexane/ $\mathrm{CH}_{2} \mathrm{Cl}_{2}$ (10:1) in $95 \%$ yield. Spectroscopic data for $\mathbf{2 b}$ (Chiraphos) are as follows. ${ }^{1} \mathrm{H}$ NMR $\left(\mathrm{CDCl}_{3}\right): \delta 8.03-7.00(\mathrm{~m}, 2 \mathrm{H}, \mathrm{Ph}), 5.30(\mathrm{br}, 1 \mathrm{H}, \mathrm{Cp}), 5.04(\mathrm{br}$, $1 \mathrm{H}, \mathrm{Cp}), 4.77$ (br, $1 \mathrm{H}, \mathrm{Cp}), 2.99(\mathrm{br}, 1 \mathrm{H}, \mathrm{Cp}), 2.87-2.79(\mathrm{~m}$, $\left.1 \mathrm{H}, \mathrm{PCH}\left(\mathrm{CH}_{3}\right)\right), 2.05-1.94\left(\mathrm{~m}, 1 \mathrm{H}, \mathrm{PCH}\left(\mathrm{CH}_{3}\right)\right), 1.69(\mathrm{~s}, 3 \mathrm{H}$, $\left.\mathrm{CH}_{3}\right), 1.06-1.00\left(\mathrm{~m}, 3 \mathrm{H}, \mathrm{PCH}\left(\mathrm{CH}_{3}\right)\right), 0.91-0.85(\mathrm{~m}, 3 \mathrm{H}, \mathrm{PCH}-$ $\left.\left(\mathrm{CH}_{3}\right)\right) \cdot{ }^{13} \mathrm{C} \mathrm{NMR}\left(\mathrm{CDCl}_{3}\right): \delta 196.9(\mathrm{~s}, \mathrm{C}=\mathrm{O}), 140.3-127.8(\mathrm{~m}$, $\mathrm{Ph}), 97.6,88.2,83.1,80.7,75.8(\mathrm{~s}, \mathrm{Cp}), 38.2-37.6(\mathrm{~m}, \mathrm{PCH}-$ $\left.\left(\mathrm{CH}_{3}\right)\right), 35.7-35.1\left(\mathrm{~m}, \mathrm{PCH}\left(\mathrm{CH}_{3}\right)\right), 28.5\left(\mathrm{~s}, \mathrm{CH}_{3}\right), 16.3-15.9(\mathrm{~m}$, $\left.\mathrm{PCH}\left(\mathrm{CH}_{3}\right)\right), 15.2-14.9\left(\mathrm{~m}, \mathrm{PCH}\left(\mathrm{CH}_{3}\right)\right)$. ${ }^{31} \mathrm{P} \mathrm{NMR}\left(\mathrm{CDCl}_{3}\right): \delta$ $81.11\left(\mathrm{~d}, J_{\mathrm{p}-\mathrm{p}}=42.5 \mathrm{~Hz}\right), 68.85\left(\mathrm{~d}, \mathrm{~J}_{\mathrm{p}-\mathrm{p}}=42.5 \mathrm{~Hz}\right)$. MS (FAB): $\mathrm{m} / \mathrm{z} 670.1\left(\mathrm{M}^{+}\right), 635.1\left(\mathrm{M}^{+}-\mathrm{Cl}\right)$. Anal. Calcd for $\mathrm{C}_{35} \mathrm{H}_{35}$ $\mathrm{OP}_{2} \mathrm{RuCl}$ : C, 62.73; H, 5.26, Found: C, 62.49; H, 4.97.

Complex 2c was obtained similarly from a thermal reaction of $\mathbf{2 a}$ with BINAP in toluene for 10 days in $90 \%$ yield. Spectroscopic data for $\mathbf{2 c}$ are as follows. ${ }^{1} \mathrm{H}$ NMR $\left(\mathrm{CDCl}_{3}\right)$ : $\delta$ 7.90-6.15 (m, 32H, Ph), 5.04 (br, 1H, Cp), 4.47 (br, 1H, Cp), $4.22(\mathrm{br}, 1 \mathrm{H}, \mathrm{Cp}), 4.12(\mathrm{br}, 1 \mathrm{H}, \mathrm{Cp}), 2.17\left(\mathrm{~s}, 3 \mathrm{H}, \mathrm{CH}_{3}\right) .{ }^{13} \mathrm{C} \mathrm{NMR}$ $\left(\mathrm{CDCl}_{3}\right): \delta 197.3(\mathrm{~s}, \mathrm{C}=\mathrm{O}), 143.1-125.4(\mathrm{~m}, \mathrm{Ph}), 95.3,89.8$, 84.2, 81.6, 77.7 (s, Cp), $29.5\left(\mathrm{~s}, \mathrm{CH}_{3}\right)$. ${ }^{31} \mathrm{P}$ NMR $\left(\mathrm{CDCl}_{3}\right): \delta 49.21$ $\left(d, J_{p-p}=54.5 \mathrm{~Hz}\right), 39.55\left(\mathrm{~d}, J_{p-p}=54.5 \mathrm{~Hz}\right) . M S(F A B): m / z$ $866.2\left(\mathrm{M}^{+}\right), 831.3\left(\mathrm{M}^{+}-\mathrm{Cl}\right)$. Anal. Calcd for $\mathrm{C}_{51} \mathrm{H}_{39} \mathrm{OP}_{2} \mathrm{RuCl}$ : C, 70.70; H, 4.54, Found: C, 70.54; $\mathrm{H}, 4.70$.

Preparation of $\left(\eta^{5}-\mathrm{CH}_{3} \mathrm{COC}_{5} \mathrm{H}_{4}\right)(\mathrm{dppe}) \mathrm{RuCl}(2 \mathrm{~d}){ }^{20} \mathrm{~A}$ solution of $0.1 \mathrm{~g}$ of $\mathrm{Ru}\left(\eta^{5}-\mathrm{CH}_{3} \mathrm{COC}_{5} \mathrm{H}_{4}\right) \mathrm{Cl}\left(\mathrm{PPh}_{3}\right)_{2}(\mathbf{2 a} ; 0.13$ $\mathrm{mmol})$ and $0.052 \mathrm{~g}(0.13 \mathrm{mmol})$ of dppe (1,2-bis(diphenyl phosphino)ethane) in toluene ( $20 \mathrm{~mL}$ ) was heated to reflux for $6 \mathrm{~h}$. The volume was reduced to $5 \mathrm{~mL}$, and $20 \mathrm{~mL}$ of light petroleum ether was added. The faint yellow precipitates were filtered off, and the filtrate was stored at $-5{ }^{\circ} \mathrm{C}$ overnight to give the product as orange crystals. Spectroscopic data for $\mathbf{2} \mathbf{d}$ are as follows. ${ }^{1} \mathrm{H}$ NMR $\left(\mathrm{CDCl}_{3}\right): \delta 7.70-7.10(\mathrm{~m}, 2 \mathrm{H}, \mathrm{Ph}), 5.29(\mathrm{br}$, $2 \mathrm{H}, \mathrm{Cp}), 4.13$ (br, 2H, Cp), 2.72-2.29 (m, 4H, $\left.\mathrm{PCH}_{2} \mathrm{CH}_{2} \mathrm{P}\right), 1.94$ $\left(\mathrm{s}, 3 \mathrm{H}, \mathrm{CH}_{3}\right) .{ }^{13} \mathrm{C} \mathrm{NMR}\left(\mathrm{CDCl}_{3}\right): \delta 196.4(\mathrm{~s}, \mathrm{C}=\mathrm{O}), 139.9-127.0$ (m, Ph), 88.4, 88.0, $66.2(\mathrm{~s}, \mathrm{Cp}), 28.1\left(\mathrm{~s}, \mathrm{CH}_{3}\right), 26.7$ (t, $\mathrm{PCH}_{2} \mathrm{CH}_{2} \mathrm{P}$, J $\mathrm{C}-\mathrm{P}=22.4 \mathrm{~Hz}$ ). ${ }^{31} \mathrm{P} N M R\left(\mathrm{CDCl}_{3}\right): \delta 78.86(\mathrm{~s})$. MS (FAB): $\mathrm{m} / \mathrm{z} 642.1\left(\mathrm{M}^{+}\right), 607.1\left(\mathrm{M}^{+}-\mathrm{Cl}\right)$. Anal. Calcd for $\mathrm{C}_{33} \mathrm{H}_{31} \mathrm{OP}_{2} \mathrm{RuCl}$ : C, 61.72; $\mathrm{H}, 4.87$. Found: $\mathrm{C}, 61.74 ; \mathrm{H}, 4.89$.

Preparation of $\left[\eta^{5} \eta^{1}-C_{5} H_{4} \mathbf{C}\left(C_{3}\right)=\mathbf{C}(P h) C(O)\right]\left(P \mathbf{P h}_{3}\right)_{2} \mathbf{R u}$ (3a). To a solution of $\mathbf{2 a}(0.25 \mathrm{~g}, 0.326 \mathrm{mmol})$ in $\mathrm{MeOH}(50$ $\mathrm{mL})$ was added $\mathrm{HC} \equiv \mathrm{CPh}(360 \mu \mathrm{L}, 3.25 \mathrm{mmol})$. The deep red solution was heated to reflux $\left(64^{\circ} \mathrm{C}\right)$ for $4 \mathrm{~h}$. The sol ution first turned to orange and finally to yell ow and, after being cooled, was concentrated to ca. $10 \mathrm{~mL}$; it was then slowly added to 70 $\mathrm{mL}$ of a stirred solution of ether. The yellow precipitate thus formed was filtered off and washed with ether. The yellow product was recrystallized from $\mathrm{CH}_{2} \mathrm{Cl}_{2}$ /ether (1:10) and identified as complex $3 \mathrm{a}(0.23 \mathrm{~g}, 86 \%)$. Spectroscopic data for 3a are as follows. IR $\left(\mathrm{cm}^{-1}, \mathrm{CH}_{2} \mathrm{Cl}_{2}\right): 1772\left(\mathrm{~s}, v_{\mathrm{C}=0}\right), 1681$ (w, $\left.v_{\mathrm{C}=\mathrm{C}}\right) .{ }^{1} \mathrm{H}$ NMR $\left(\mathrm{CDCl}_{3}\right): \delta 7.36-7.02(\mathrm{~m}, 35 \mathrm{H}, \mathrm{Ph}), 4.67(\mathrm{br}$, $2 \mathrm{H}, \mathrm{Cp}), 3.92(\mathrm{br}, 2 \mathrm{H}, \mathrm{Cp}), 2.12\left(\mathrm{~s}, 3 \mathrm{H}, \mathrm{CH}_{3}\right) .{ }^{13} \mathrm{C} \mathrm{NMR}$ $\left(\mathrm{CDCl}_{3}\right): \delta 247.7(\mathrm{t}, \mathrm{J} \mathrm{c}-\mathrm{p}=12.5 \mathrm{~Hz}, \mathrm{C}=\mathrm{O}), 168.1$ (s, COCPh), $142.3\left(\mathrm{~s}, \mathrm{CCH}_{3}\right), 140.7-124.7(\mathrm{~m}, \mathrm{Ph}), 126.3,94.4,83.3(\mathrm{~s}, \mathrm{Cp})$ $19.3\left(\mathrm{~s}, \mathrm{CH}_{3}\right)$. $31 \mathrm{P}$ NMR $\left(\mathrm{CDCl}_{3}\right): \delta 49.13(\mathrm{~s}) . \mathrm{MS}(\mathrm{FAB}): \mathrm{m} / \mathrm{z}$ $834.4\left(\mathrm{M}^{+}\right), 572.2\left(\mathrm{M}^{+}-\mathrm{PPh}_{3}\right), 543.2\left(\mathrm{M}^{+}-\mathrm{PPh}_{3}, \mathrm{CO}\right), 467.1$ $\left(\mathrm{M}^{+}-\mathrm{PPh}_{3}, \mathrm{CO}, \mathrm{Ph}\right)$. Anal. Calcd for $\mathrm{C}_{51} \mathrm{H}_{42} \mathrm{OP}_{2} \mathrm{Ru}$ : C, 73.45; $H, 5.08$. Found: C, 73.67; $H, 4.96$.

Preparation of $\left[\eta^{5} \eta^{1}-\mathrm{C}_{5} \mathrm{H}_{4} \mathrm{C}\left(\mathrm{CH}_{3}\right)=\mathrm{C}(\mathrm{Ph}) \mathrm{C}(\mathrm{O})\right](\mathrm{Chira}-$ phos)Ru (3b). To a solution of $\mathbf{2 b}(100 \mathrm{mg}, 0.15 \mathrm{mmol})$ in anhydrous $\mathrm{MeOH}(20 \mathrm{~mL})$ was added phenylacetylene $(50 \mu \mathrm{L}$, $0.45 \mathrm{mmol}$ ), and the mixture was heated to reflux for $3 \mathrm{~h}$. Then the yellow solution was evaporated to dryness, and the residue was recrystallized from $\mathrm{CH}_{2} \mathrm{Cl}_{2} / \mathrm{n}$-hexane to give a yellow powder identified as $\mathbf{3 b}$ (89 $\mathrm{mg}, 81 \%$ yield). Spectroscopic data are as follows. ${ }^{1} \mathrm{H} \mathrm{NMR}\left(\mathrm{CDCl}_{3}\right): \delta 7.57-6.49(\mathrm{~m}, 25 \mathrm{H}, \mathrm{Ph})$,

(20) Alonso, A. G.; Reventós, L. B. J . Organomet. Chem. 1988, 338, 249. 
$5.61(\mathrm{br}, 1 \mathrm{H}, \mathrm{Cp}), 5.46(\mathrm{br}, 1 \mathrm{H}, \mathrm{Cp}), 4.76(\mathrm{br}, 1 \mathrm{H}, \mathrm{Cp}), 4.64(\mathrm{br}$, $1 \mathrm{H}, \mathrm{Cp}), 3.62-3.40\left(\mathrm{~m}, 1 \mathrm{H}, \mathrm{PCH}\left(\mathrm{CH}_{3}\right)\right), 2.15-1.99(\mathrm{~m}, 1 \mathrm{H}$, $\left.\mathrm{PCH}\left(\mathrm{CH}_{3}\right)\right), 1.91\left(\mathrm{~s}, 3 \mathrm{H}, \mathrm{CH}_{3}\right), 1.36-1.28\left(\mathrm{~m}, 3 \mathrm{H}, \mathrm{PCH}\left(\mathrm{CH}_{3}\right)\right)$, $0.93-0.88\left(\mathrm{~m}, 3 \mathrm{H}, \mathrm{PCH}\left(\mathrm{CH}_{3}\right)\right) .{ }^{13} \mathrm{C} \mathrm{NMR}\left(\mathrm{CDCl}_{3}\right): \delta 257.6(\mathrm{dd}$, $\mathrm{J} \mathrm{c}-\mathrm{P}=16.1,11.7 \mathrm{~Hz}, \mathrm{C}=\mathrm{O}), 153.0(\mathrm{~s}, \mathrm{COCPh}), 143.0\left(\mathrm{~s}, \mathrm{CCH}_{3}\right)$, $138.2-124.7(\mathrm{~m}, \mathrm{Ph}), 95.2,92.5,91.6,86.6,67.8(\mathrm{~s}, \mathrm{Cp}), 41.5-$ $40.9\left(\mathrm{~m}, \mathrm{PCH}\left(\mathrm{CH}_{3}\right)\right), 34.1-33.5\left(\mathrm{~m}, \mathrm{PCH}\left(\mathrm{CH}_{3}\right)\right), 27.4\left(\mathrm{~s}, \mathrm{CH}_{3}\right)$, 15.3-14.9 (m, PCH $\left.\left(\mathrm{CH}_{3}\right)\right)$. ${ }^{31} \mathrm{P} \mathrm{NMR}\left(\mathrm{CDCl}_{3}\right): \delta 93.69(\mathrm{~d}, \mathrm{~J}$ P-P $=36.5 \mathrm{~Hz}$ ), $91.32\left(\mathrm{~d}, \mathrm{~J}_{\mathrm{P}-\mathrm{P}}=36.5 \mathrm{~Hz}\right.$ ). Anal. Calcd for $\mathrm{C}_{43} \mathrm{H}_{40^{-}}$ $\mathrm{OP}_{2} \mathrm{Ru}: \mathrm{C}, 70.19 ; \mathrm{H}, 5.48$. Found: $\mathrm{C}, 70.41 ; \mathrm{H}, 5.79$.

Preparation of $\left[\eta^{5} \eta^{1}-C_{5} H_{4} C\left(C_{3}\right)=C(P h) C(O)\right](R-B I-$ NAP)Ru (3c). To a suspension of $\mathbf{2 c}(100 \mathrm{mg}, 0.12 \mathrm{mmol})$ in anhydrous $\mathrm{MeOH}(20 \mathrm{~mL})$ was added phenylacetylene ( $39 \mu \mathrm{L}$, $0.36 \mathrm{mmol}$ ). The orange solution was heated to reflux for $5 \mathrm{~h}$ and subsequently cooled to room temperature. The solvent was removed under vacuum and the residue recrystallized from $\mathrm{CH}_{2} \mathrm{Cl}_{2} /$ n-hexane to give $3 \mathrm{c}$ as a microcrystalline yellow solid (yield: $81 \mathrm{mg}, 72 \%$ ). Spectroscopic data for $3 \mathrm{c}$ are as follows. ${ }^{1} \mathrm{H} \mathrm{NMR}\left(\mathrm{CDCl}_{3}\right): \delta 7.66-6.09(\mathrm{~m}, 37 \mathrm{H}, \mathrm{Ph}), 5.00,4.89,4.37$, $3.63(\mathrm{br}, 4 \mathrm{H}, \mathrm{Cp}), 1.96\left(\mathrm{~s}, 3 \mathrm{H}, \mathrm{CH}_{3}\right) .{ }^{13} \mathrm{C} \mathrm{NMR}\left(\mathrm{CDCl}_{3}\right): \delta 245.7$ (dd, J c-p = 10.2, $6.4 \mathrm{~Hz}, \mathrm{C}=\mathrm{O}), 168.3$ (s, COCPh), 145.6 (s, $\left.\mathrm{CCH}_{3}\right), 145.1-127.0(\mathrm{~m}, \mathrm{Ph}), 94.1,90.0,89.0,87.2,84.5$ (s, Cp), $19.6\left(\mathrm{~s}, \mathrm{CH}_{3}\right) .{ }^{31} \mathrm{P} \mathrm{NMR}\left(\mathrm{CDCl}_{3}\right): \delta 63.36(\mathrm{~d}, \mathrm{~J} \mathrm{p}-\mathrm{p}=47.5 \mathrm{~Hz})$, $56.76\left(d, J_{P-P}=47.5 \mathrm{~Hz}\right)$. MS (FAB): $\mathrm{m} / \mathrm{z} 932.3\left(\mathrm{M}^{+}\right)$. Anal. Calcd for $\mathrm{C}_{59} \mathrm{H}_{44} \mathrm{OP}_{2} \mathrm{Ru}$ : C, 76.03; $\mathrm{H}, 4.76$. Found: C, 76.15; $\mathrm{H}, 4.87$.

Preparation of $\left[\eta^{5} \eta^{1}-C_{5} \mathrm{H}_{4} \mathrm{C}\left(\mathrm{CH}_{3}\right)=\mathrm{C}(\mathrm{Ph}) \mathrm{C}(\mathrm{O})\right]$ (dppe)$\mathbf{R u}$ (3d). To a solution of $\mathbf{2 d}$ ( $25 \mathrm{mg}, 0.04 \mathrm{mmol}$ ) in anhydrous methyl alcohol $(20 \mathrm{~mL})$ was added phenylacetylene $(45 \mu \mathrm{L}, 0.40$ $\mathrm{mmol})$, and the mixture was heated to reflux for $6 \mathrm{~h}$. Then the yel low solution was evaporated to dryness and the residue was recrystallized with $\mathrm{CH}_{2} \mathrm{Cl}_{2} /$ n-hexane to give a yellow powder identified as 3d (15 mg, 65\% yield). Spectroscopic data for 3d are as follows. ${ }^{1} \mathrm{H}$ NMR $\left(\mathrm{CDCl}_{3}\right): \delta 7.69-6.95(\mathrm{~m}, 25 \mathrm{H}$, $\mathrm{Ph}), 5.59$ (br, 2H, Cp), 4.72 (br, 2H, Cp), 2.72-2.29 (m, 4H, $\left.\mathrm{PCH}_{2} \mathrm{CH}_{2} \mathrm{P}\right), 1.82\left(\mathrm{~s}, 3 \mathrm{H}, \mathrm{CH}_{3}\right) .{ }^{13} \mathrm{C} \mathrm{NMR}\left(\mathrm{CDCl}_{3}\right): \delta 254.9(\mathrm{t}$, $\left.\mathrm{J}_{\mathrm{C}-\mathrm{P}}=14.0 \mathrm{~Hz}, \mathrm{C}=\mathrm{O}\right), 167.9(\mathrm{~s}, \mathrm{COCPh}), 144.1\left(\mathrm{~s}, \mathrm{CCH}_{3}\right)$, 138.6-125.4 (m, Ph), 92.8, 86.4, $68.8(\mathrm{~s}, \mathrm{Cp}), 29.7-27.5(\mathrm{t}$, $\mathrm{PCH}_{2} \mathrm{CH}_{2} \mathrm{P}$, J $\left.\mathrm{C}-\mathrm{P}=21.4 \mathrm{~Hz}\right), 19.8\left(\mathrm{~s}, \mathrm{CH}_{3}\right)$. ${ }^{31} \mathrm{P} \mathrm{NMR}$ $\left(\mathrm{CDCl}_{3}\right): \delta 96.50$ (s). MS (FAB): $\mathrm{m} / \mathrm{z} 708.2\left(\mathrm{M}^{+}\right)$. Anal. Calcd for $\mathrm{C}_{41} \mathrm{H}_{36} \mathrm{OP}_{2} \mathrm{Ru}$ : C, 69.58; H, 5.13. Found: $\mathrm{C}, 69.44 ; \mathrm{H}, 4.98$.

Spectroscopic Observation of $\left\{\left(\eta^{5}-\mathrm{C}_{5} \mathrm{H}_{4} \mathrm{COCH}_{3}\right)-\right.$ $\left.(\mathbf{P P h})_{2} \mathbf{R} \mathbf{u}=\mathbf{C}=\mathbf{C H P h}\right\} \mathbf{C I}$ (4a). The same reaction was carried out in an oil bath with the temperature maintained at 50 ${ }^{\circ} \mathrm{C}$ for $3 \mathrm{~h}$ to give an orange mixture. The solvent of this mixture was removed under vacuum, and the residue was redissolved in $\mathrm{CDCl}_{3}$. The ${ }^{31} \mathrm{P} \mathrm{NMR}$ spectrum of this solution indicated formation of the intermediate $\mathbf{4 a}$ as well as $\mathbf{3 a}$ in a ratio of roughly $1: 1$. Attempts to isolate $\mathbf{4 a}$ by column chromatography led to decomposition. Only a yellow band, identified as 3a, was obtained. Spectroscopic data for $\mathbf{4 a}$ were obtained from the mixture of products. ${ }^{1} \mathrm{H} \mathrm{NMR}\left(\mathrm{CDCl}_{3}\right): \delta$ 7.69-6.95 (m, 35H, Ph), $5.03(\mathrm{br}, 2 \mathrm{H}, \mathrm{Cp}), 4.74(\mathrm{~s}, 1 \mathrm{H}$, $\mathrm{C}=\mathrm{CH}(\mathrm{Ph})), 4.56(\mathrm{br}, 2 \mathrm{H}, \mathrm{Cp}), 2.28\left(\mathrm{~s}, 3 \mathrm{H}, \mathrm{CH}_{3}\right) .{ }^{31} \mathrm{P} N M R$ $\left(\mathrm{CDCl}_{3}\right): \delta 42.87$ (s). F urther heating of the mixture in $\mathrm{MeOH}$ converted this intermediate to $\mathbf{3 a}$.

Isolation of $\left(\eta^{5}-\mathrm{C}_{5} \mathrm{H}_{4} \mathrm{COCH}_{3}\right)\left(\mathrm{PPh}_{3}\right)_{2} \mathrm{RuC} \equiv \mathbf{C P h}(5 \mathrm{a})$. I the presence of $\mathrm{NaOMe}(20 \mathrm{mg})$, the reaction of $\mathbf{2 a}(0.051 \mathrm{~g}$, $0.064 \mathrm{mmol})$ with excess $\mathrm{HC} \equiv \mathrm{CPh}(72 \mu \mathrm{L}, 0.65 \mathrm{mmol})$ in $\mathrm{MeOH}$ gave $\mathbf{3 a}$ and the acetylide complex $\mathbf{5 a}$ in a 1:2 ratio. Column chromatographic separation of the mixture eluted by n-hexane $/ \mathrm{CH}_{2} \mathrm{Cl}_{2}$ (1:5) gave two yellow bands, $\mathbf{5 a}$ and $\mathbf{3 a}$. Spectroscopic data of $\mathbf{5 a}$ are as follows. ${ }^{1} \mathrm{H} \mathrm{NMR}\left(\mathrm{CDCl}_{3}\right): \delta$ 7.30-6.89 (m, 35H, Ph), 4.59 (br, 2H, Cp), 3.80 (br, 2H, Cp), $2.57\left(\mathrm{~s}, 3 \mathrm{H}, \mathrm{CH}_{3}\right)$. ${ }^{31} \mathrm{P} \mathrm{NMR}\left(\mathrm{CDCl}_{3}\right): \delta 51.85(\mathrm{~s})$. MS (FAB): $\mathrm{m} / \mathrm{z} 834.4\left(\mathrm{M}^{+}\right), 692.3\left(\mathrm{M}^{+}-\mathrm{CCPh}, \mathrm{COCH}_{3}\right)$. In the presence of $\mathrm{CF}_{3} \mathrm{COOH}, \mathbf{5} \mathbf{a}$ in $\mathrm{CDCl}_{3}$ cleanly converted to $\mathbf{3} \mathbf{a}$ in a NMR tube in $4 \mathrm{~h}$. Anal. Calcd for $\mathrm{C}_{51} \mathrm{H}_{42} \mathrm{OP}_{2} \mathrm{Ru}$ : C, 73.45; $\mathrm{H}, 5.08$.

Preparation of $\left[\eta^{5}-\mathrm{C}_{5} \mathrm{H}_{4} \mathrm{C}(\mathrm{CCPh})(\mathrm{OH}) \mathrm{CH}_{3}\right]\left(\mathrm{PPh}_{3}\right)_{2} \mathrm{RuCl}$ (6a). To a solution of $\mathbf{2 a}$ (102 $\mathrm{mg}, 0.13 \mathrm{mmol}$ in $10 \mathrm{~mL}$ of $\mathrm{CH}_{2} \mathrm{Cl}_{2}$ ) exposed to air was added lithium phenylacetylide (390 $\mu \mathrm{L}, 0.39 \mathrm{mmol}$ in $1 \mathrm{M} \mathrm{THF})$. The reaction mixture was stirred at room temperature for $30 \mathrm{~min}$. Then the solvent was removed under vacuum. The residue was extracted with $1 \mathrm{~mL}$ of $\mathrm{CH}_{2} \mathrm{Cl}_{2}$, and $\mathrm{n}$-hexane ( $2 \mathrm{~mL}$ ) was added to remove the salt after filtration. Then the solvent was removed under vacuum and the residue recrystallized in two stages from dichloromethane/n-hexane to give red crystals of $\mathbf{6 a}(67 \mathrm{mg}, 60 \%$ yield); $\mathrm{OPPh}_{3}$ (11 mg, 30\% yield) was obtained as a byproduct. Spectroscopic data of 6 a are as follows. ${ }^{1} \mathrm{H} \mathrm{NMR}\left(\mathrm{CDCl}_{3}\right): \delta$ 7.69-6.97 (m, 35H, Ph), $6.27(\mathrm{br}, 1 \mathrm{H}, \mathrm{OH}), 4.31$ (br, 1H, Cp), $4.08(\mathrm{br}, 1 \mathrm{H}, \mathrm{Cp}), 3.73(\mathrm{br}, 1 \mathrm{H}, \mathrm{Cp}), 3.32(\mathrm{br}, 1 \mathrm{H}, \mathrm{Cp}), 1.79(\mathrm{~s}$, $\left.3 \mathrm{H}, \mathrm{CH}_{3}\right) .{ }^{13} \mathrm{C} \mathrm{NMR}\left(\mathrm{CDCl}_{3}\right): \delta 138.1-123.4(\mathrm{~m}, \mathrm{Ph}), 121.1$ (chiral carbon), $92.8(\mathrm{~s}, \mathrm{C} \equiv \mathrm{CPh}), 84.2(\mathrm{~s}, \mathrm{C} \equiv \mathrm{CPh}), 73.8,77.6$, 72.8, 77.2, 67.0 (s, Cp), $33.8\left(\mathrm{~s}, \mathrm{CH}_{3}\right)$. ${ }^{31} \mathrm{P} \mathrm{NMR}\left(\mathrm{CDCl}_{3}\right): \delta 39.01$ $(\mathrm{d}, \mathrm{J}-\mathrm{p}=41.4 \mathrm{~Hz}), 38.20(\mathrm{~d}, \mathrm{~J}-\mathrm{p}=41.4 \mathrm{~Hz}) . \mathrm{MS}(\mathrm{FAB}): \mathrm{m} / \mathrm{z}$ $870.1\left(\mathrm{M}^{+}\right), 834.2\left(\mathrm{M}^{+}-\mathrm{Cl}\right), 733.2\left(\mathrm{M}^{+}-\mathrm{Cl}, \mathrm{CCPh}\right) . \mathrm{A}$ satisfactory elemental analysis was not obtained due to the instability of the complex. The same reaction in THF or in $\mathrm{CH}_{2} \mathrm{Cl}_{2}$ under nitrogen gave a complicated mixture of products.

Preparation of $\mathbf{6 b}$ was similarly carried out using the same procedure. A mixture containing diastereomers of $\mathbf{6 b}$ was obtained after purification. No attempt was made to separate these diastereomers. Spectroscopic data for $\mathbf{6 b}$ (chiraphos) are as follows. Major product: ${ }^{1} \mathrm{H}$ NMR $\left(\mathrm{CDCl}_{3}\right) \delta 8.05-7.04(\mathrm{~m}$, $25 \mathrm{H}, \mathrm{Ph}), 5.64(\mathrm{br}, 1 \mathrm{H}, \mathrm{OH}), 5.15(\mathrm{br}, 1 \mathrm{H}, \mathrm{Cp}), 5.07$ (br, $1 \mathrm{H}$, $\mathrm{Cp}), 4.58(\mathrm{br}, 1 \mathrm{H}, \mathrm{Cp}), 4.23(\mathrm{br}, 1 \mathrm{H}, \mathrm{Cp}), 2.63-2.50(\mathrm{~m}, 1 \mathrm{H}$, $\left.\mathrm{PCH}\left(\mathrm{CH}_{3}\right)\right), 2.06-1.95\left(\mathrm{~m}, 1 \mathrm{H}, \mathrm{PCH}\left(\mathrm{CH}_{3}\right)\right), 1.71\left(\mathrm{~s}, 3 \mathrm{H}, \mathrm{CH}_{3}\right)$, 1.03-0.94 (m, 3H, PCH $\left.\left(\mathrm{CH}_{3}\right)\right), 0.87-0.82\left(\mathrm{~m}, 3 \mathrm{H}, \mathrm{PCH}\left(\mathrm{CH}_{3}\right)\right)$; ${ }^{13} \mathrm{C} \mathrm{NMR}\left(\mathrm{CDCl}_{3}\right) \delta 136.5-127.1(\mathrm{~m}, \mathrm{Ph}), 118.4$ (s, chiral carbon), 92.8 (s, $\mathrm{C} \equiv \mathrm{CPh}$ ), 82.8 (s, $\mathrm{C} \equiv \mathrm{CPh}), 81.8,81.3,80.8$, 72.3, $67.0(\mathrm{~s}, \mathrm{Cp}), 37.7-36.2\left(\mathrm{~m}, \mathrm{PCH}\left(\mathrm{CH}_{3}\right)\right), 34.1\left(\mathrm{~s}, \mathrm{CH}_{3}\right)$, 15.5-14.1 (m, PCH $\left.\left(\mathrm{CH}_{3}\right)\right)$; ${ }^{31} \mathrm{P}$ NMR $\left(\mathrm{CDCl}_{3}\right) \delta 85.13$ (d, J P-P $=40.6 \mathrm{~Hz}), 64.96(\mathrm{~d}, \mathrm{~J} \mathrm{p}-\mathrm{p}=40.6 \mathrm{~Hz})$. Minor product: ${ }^{1} \mathrm{H}$ NMR $\left(\mathrm{CDCl}_{3}\right) \delta 8.05-7.04(\mathrm{~m}, 25 \mathrm{H}, \mathrm{Ph}), 7.14(\mathrm{br}, 1 \mathrm{H}, \mathrm{OH}), 4.70(\mathrm{br}$, $1 \mathrm{H}, \mathrm{Cp}), 3.58$ (br, 1H, Cp), 3.18 (br, 1H, Cp), 2.58 (br, 1H, Cp), $2.63-2.50\left(\mathrm{~m}, 1 \mathrm{H}, \mathrm{PCH}\left(\mathrm{CH}_{3}\right)\right), 2.06-1.95\left(\mathrm{~m}, 1 \mathrm{H}, \mathrm{PCH}\left(\mathrm{CH}_{3}\right)\right)$, $1.80\left(\mathrm{~s}, 3 \mathrm{H}, \mathrm{CH}_{3}\right), 1.03-0.94\left(\mathrm{~m}, 3 \mathrm{H}, \mathrm{PCH}\left(\mathrm{CH}_{3}\right)\right), 0.87-0.82$ $\left(\mathrm{m}, 3 \mathrm{H}, \mathrm{PCH}\left(\mathrm{CH}_{3}\right)\right) ;{ }^{13} \mathrm{C} \mathrm{NMR}\left(\mathrm{CDCl}_{3}\right) \delta 136.5-127.1(\mathrm{~m}, \mathrm{Ph})$, 118.3 (s, chiral carbon), 93.0 (s, $\mathrm{C} \equiv \mathrm{CPh}), 83.0$ (s, $\mathrm{C} \equiv \mathrm{CPh}), 75.9$, 74.6, 72.2, 67.5, 66.6 (s, $\mathrm{Cp}), 37.7-36.2\left(\mathrm{~m}, \mathrm{PCH}\left(\mathrm{CH}_{3}\right)\right), 31.5$ $\left(\mathrm{s}, \mathrm{CH}_{3}\right), 15.5-14.1\left(\mathrm{~m}, \mathrm{PCH}\left(\mathrm{CH}_{3}\right)\right) ;{ }^{31} \mathrm{P} \mathrm{NMR}\left(\mathrm{CDCl}_{3}\right) \delta 84.30$ $\left(d, J_{p-p}=42.7 \mathrm{~Hz}\right), 65.80\left(\mathrm{~d}, J_{\mathrm{p}-\mathrm{p}}=42.7 \mathrm{~Hz}\right)$.

Spectroscopic data for $\mathbf{6 c}$ (BINAP) are as follows. Major product: ${ }^{1} \mathrm{H}$ NMR $\left(\mathrm{CDCl}_{3}\right) \delta 7.29-6.17(\mathrm{~m}, 37 \mathrm{H}, \mathrm{Ph}), 6.24(\mathrm{br}$, $1 \mathrm{H}, \mathrm{OH}), 4.33$ (br, $1 \mathrm{H}, \mathrm{Cp}), 4.32(\mathrm{br}, 1 \mathrm{H}, \mathrm{Cp}), 4.25$ (br, $1 \mathrm{H}$, $\mathrm{Cp}), 3.46(\mathrm{br}, \mathrm{H}, \mathrm{Cp}), 1.77\left(\mathrm{~s}, 3 \mathrm{H}, \mathrm{CH}_{3}\right) ;{ }^{13} \mathrm{C} \mathrm{NMR}\left(\mathrm{CDCl}_{3}\right) \delta$ 142.5-119.2 (m, Ph), 118.2 (s, chiral carbon), $92.8(\mathrm{~s}, \mathrm{C} \equiv \mathrm{CPh})$, 83.1 (s, $\mathrm{C} \equiv \mathrm{CPh}), 85.0,81.1,75.9,69.3,66.6$ (s, Cp), 31.2 (s, $\left.\mathrm{CH}_{3}\right) ;{ }^{31} \mathrm{P} \mathrm{NMR}\left(\mathrm{CDCl}_{3}\right) \delta 53.17(\mathrm{~d}, \mathrm{~J}$ P-P $=52.1 \mathrm{~Hz}), 37.23(\mathrm{~d}$ $\left.\mathrm{J}_{\mathrm{P}-\mathrm{P}}=52.1 \mathrm{~Hz}\right)$. Minor product: ${ }^{1} \mathrm{H} \mathrm{NMR}\left(\mathrm{CDCl}_{3}\right) \delta 7.29-$ $6.17(\mathrm{~m}, 37 \mathrm{H}, \mathrm{Ph}), 6.18(\mathrm{br}, 1 \mathrm{H}, \mathrm{OH}), 4.20(\mathrm{br}, 1 \mathrm{H}, \mathrm{Cp}), 3.72$ (br, 1H, Cp), 3.59 (br, 1H, Cp), 3.55 (br, 1H, Cp), 1.70 (s, 3H, $\left.\mathrm{CH}_{3}\right) ;{ }^{13} \mathrm{C} \mathrm{NMR}\left(\mathrm{CDCl}_{3}\right) \delta 142.5-119.2(\mathrm{~m}, \mathrm{Ph}), 118.0$ (s, chiral carbon), $93.2(\mathrm{~s}, \mathrm{C} \equiv \mathrm{CPh}), 83.0(\mathrm{~s}, \mathrm{C} \equiv \mathrm{CPh}), 86.1,81.4,72.8$, 67.5, 65.4, (s, Cp), 35.5 (s, $\left.\mathrm{CH}_{3}\right) ;{ }^{31} \mathrm{P} \mathrm{NMR}\left(\mathrm{CDCl}_{3}\right) \delta 53.69$ (d, $\left.J_{p-p}=52.3 \mathrm{~Hz}\right), 41.67(\mathrm{~d}, \mathrm{~J} p-\mathrm{p}=52.3 \mathrm{~Hz}) ; \mathrm{MS}(\mathrm{FAB}) \mathrm{m} / \mathrm{z} 968.0$ $\left(\mathrm{M}^{+}\right), 932.3\left(\mathrm{M}^{+}-\mathrm{Cl}\right), 831.3\left(\mathrm{M}^{+}-\mathrm{Cl}, \mathrm{CCPh}\right)$.

Spectroscopic data for $\mathbf{6 d}$ (dppe) are as follows. ${ }^{1} \mathrm{H}$ NMR $\left(\mathrm{CDCl}_{3}\right): \delta 8.01-6.96(\mathrm{~m}, 25 \mathrm{H}, \mathrm{Ph}), 5.55(\mathrm{br}, 1 \mathrm{H}, \mathrm{OH}), 5.33$ (br, $1 \mathrm{H}, \mathrm{Cp}), 5.26$ (br, 1H, Cp), 3.88 (br, 1H, Cp), 2.89 (br, 1H, $\mathrm{Cp}), 2.72-2.31\left(\mathrm{~m}, 4 \mathrm{H}, \mathrm{PCH}_{2} \mathrm{CH}_{2} \mathrm{P}\right), 1.87\left(\mathrm{~s}, 3 \mathrm{H}, \mathrm{CH}_{3}\right) .{ }^{13} \mathrm{C}$ NMR $\left(\mathrm{CDCl}_{3}\right): \delta 142.1-23.2(\mathrm{~m}, \mathrm{Ph}), 116.6$ (s, chiral carbon), 92.9 (s, $\mathrm{C} \equiv \mathrm{CPh}$ ), 83.4 (s, $\mathrm{C} \equiv \mathrm{CPh}$ ), 72.6, 79.5, 77.8, 70.0, 67.0 (s, Cp), $33.8\left(\mathrm{~s}, \mathrm{CH}_{3}\right), 27.9-26.5\left(\mathrm{~m}, \mathrm{PCH}_{2} \mathrm{CH}_{2} \mathrm{P}\right)$. ${ }^{31} \mathrm{P} N M R$ $\left(\mathrm{CDCl}_{3}\right): \delta 80.95(\mathrm{~d}, \mathrm{~J} \mathrm{p}-\mathrm{p}=26.4 \mathrm{~Hz}), 76.43(\mathrm{~d}, \mathrm{~J} \mathrm{p}-\mathrm{p}=26.4$ Hz). MS (FAB): m/z 744.3 $\left(\mathrm{M}^{+}\right), 727.3\left(\mathrm{M}^{+}-\mathrm{OH}\right), 708.8\left(\mathrm{M}^{+}\right.$ $-\mathrm{Cl}), 691.3\left(\mathrm{M}^{+}-\mathrm{Cl}, \mathrm{OH}\right), 607.2\left(\mathrm{M}^{+}-\mathrm{Cl}, \mathrm{CCPh}\right)$. Anal. Calcd for $\mathrm{C}_{43} \mathrm{H}_{37} \mathrm{OP}_{2} \mathrm{RuCl}$ : C, 66.17; $\mathrm{H}, 5.01$. Found: $\mathrm{C}, 66.35$; $\mathrm{H}, 5.12$.

Transformation of $6 \mathbf{a}$ to $3 a$. Complex $6 \mathbf{a}(88 \mathrm{mg})$ was passed through a column packed with neutral aluminum oxide 
Table 3. Crystal and Intensity Collection Data for $\left[\eta^{5}: \eta^{1}-\mathrm{C}_{5} \mathrm{H}_{4} \mathrm{C}\left(\mathrm{CH}_{3}\right)=\mathrm{C}(\mathrm{Ph}) \mathrm{C}(\mathrm{O})\right]\left(\mathrm{PPh}_{3}\right)_{2} \mathrm{Ru}(\mathrm{3a})$ and $\left[\left(\eta^{5}-\mathrm{C}_{5} \mathrm{H}_{4} \mathrm{C}(\mathrm{CCPh})(\mathrm{OH}) \mathrm{CH}_{3}\right)\right](\mathrm{Chi}$ raphos $) \mathrm{RuCl}(6 \mathrm{~b})$

\begin{tabular}{|c|c|c|}
\hline & 3a & $6 b$ \\
\hline $\begin{array}{l}\text { mol formula } \\
\text { mol wt }\end{array}$ & $\begin{array}{l}\mathrm{C}_{51} \mathrm{H}_{42} \mathrm{OP}_{2} \mathrm{Ru} \\
833.86\end{array}$ & $\begin{array}{l}\mathrm{C}_{43} \mathrm{H}_{41} \mathrm{ClOP}_{2} \mathrm{Ru} \\
772.22\end{array}$ \\
\hline space group & Pnma & $\mathrm{P} 2_{1}$ \\
\hline$a, \AA$ & $18.5681(4)$ & $9.3200(3)$ \\
\hline $\mathrm{b}, \AA$ & $15.2878(2)$ & 19.1980(5) \\
\hline$c, \AA$ & $14.1439(3)$ & $11.2600(2)$ \\
\hline$\alpha(\mathrm{deg})$ & 90 & 90 \\
\hline$\beta$ (deg) & 90 & 109.39(3) \\
\hline$\gamma$ (deg) & 90 & 90 \\
\hline$V, \AA^{3}$ & 4014.96(13) & 1900.39(9) \\
\hline $\mathrm{Z}$ & 4 & 2 \\
\hline cryst dimens, $\mathrm{mm}^{3}$ & $0.20 \times 0.10 \times 0.10$ & $0.35 \times 0.30 \times 0.25$ \\
\hline MoK $\alpha$ radiation: $\lambda, \AA$ & 0.71073 & 0.71073 \\
\hline $\begin{array}{l}\theta \text { range for data } \\
\text { collection, deg }\end{array}$ & $1.81-23.29$ & $1.92-27.50$ \\
\hline limiting indices $(h, k, l)$ & $\begin{array}{l}-20 \text { to }+18 ; \\
-12 \text { to }+16 ; \\
-15 \text { to }+8\end{array}$ & $\begin{array}{l}-12 \text { to }+11 \\
\quad-24 \text { to }+23 \\
-14 \text { to }+14\end{array}$ \\
\hline no. of rflns collected & 11876 & 53516 \\
\hline no. of indep rflns & 2969 & 7138 \\
\hline $\begin{array}{l}\text { max and min } \\
\text { transmission }\end{array}$ & 0.639 and 0.585 & 0.865 and 0.686 \\
\hline refinement method & \multicolumn{2}{|c|}{ full-matrix least squares on $\mathrm{F}^{2}$} \\
\hline $\begin{array}{l}\text { no. of data/restraints/ } \\
\text { params }\end{array}$ & $2730 / 0 / 263$ & $7138 / 1 / 434$ \\
\hline GOF & 1.167 & 1.320 \\
\hline $\begin{array}{l}\text { final } R \text { indices } \\
\text { for } 1>2 \sigma(l)\end{array}$ & & \\
\hline for all data & $\begin{array}{l}0.0330 / 0.0102 \\
0.0551 / 0.0798\end{array}$ & $\begin{array}{l}0.0418 / 0.1035 \\
0.0432 / 0.1082\end{array}$ \\
\hline$\Delta \rho$ (in final map), e $/ \AA^{3}$ & $0.3570,-0.354$ & $0.8350,-0.968$ \\
\hline
\end{tabular}

eluted by $\mathrm{CH}_{2} \mathrm{Cl}_{2}$. The red band changed to yellow in the column. The solvent of the yellow fraction collected was removed under vacuum to give 3 a (65 $\mathrm{mg}, 78 \%$ yield). This transformation is also observed in $\mathrm{CDCl}_{3}$ when $\mathrm{NaOMe}$ was added to a solution of $\mathbf{6} \mathbf{a}$ in a NMR tube. The NMR yield was about $50 \%$.

I solation of $\left(\eta^{5}-\mathrm{C}_{5} \mathrm{H}_{4} \mathrm{COCH}_{3}\right)(\mathrm{R}-\mathrm{BINAP}) \mathrm{RuC} \equiv \mathrm{CPh}(5 \mathrm{c})$. Transformation of $\mathbf{6 c}$ to $\mathbf{5} \mathbf{c}$ was performed by chromatography on an alumina-packed column, and $\mathrm{CH}_{2} \mathrm{Cl}_{2}$ was used as eluent; the product was isol ated as a yellow solid and was purified by recrystallization from $\mathrm{CH}_{2} \mathrm{Cl}_{2} / \mathrm{n}$-hexane. Spectroscopic data for $5 \mathrm{c}$ are as follows. ${ }^{1 \mathrm{H}} \mathrm{NMR}\left(\mathrm{CDCl}_{3}\right): \delta 7.96-6.20(\mathrm{~m}, 37 \mathrm{H}, \mathrm{Ph})$, 4.83, 4.68, 4.35, $4.30(\mathrm{br}, 4 \mathrm{H}, \mathrm{Cp}), 2.31\left(\mathrm{~s}, 3 \mathrm{H}, \mathrm{CH}_{3}\right) .{ }^{13} \mathrm{C} \mathrm{NMR}$ $\left(\mathrm{CDCl}_{3}\right): \delta 197.1(\mathrm{~s}, \mathrm{C}=\mathrm{O}), 150.2-121.5(\mathrm{~m}, \mathrm{Ph}), 118.3(\mathrm{t}, \mathrm{J} \mathrm{c}-\mathrm{P}$ $=22.6 \mathrm{~Hz}, \mathrm{C} \equiv \mathrm{CPh}), 114.2(\mathrm{~s}, \mathrm{C} \equiv \mathrm{CPh}), 95.9$, 93.4, 88.9, 85.3, $83.9(\mathrm{~s}, \mathrm{Cp}), 29.0\left(\mathrm{~s}, \mathrm{CH}_{3}\right) .{ }^{31} \mathrm{P}$ NMR $\left(\mathrm{CDCl}_{3}\right): \delta 57.60(\mathrm{~d}, \mathrm{~J}$ p-p $=47.6 \mathrm{~Hz}), 47.40(\mathrm{~d}, \mathrm{~J}$ - $-\mathrm{p}=47.6 \mathrm{~Hz}) . \mathrm{MS}(\mathrm{FAB}): \mathrm{m} / \mathrm{z} 932.3$ $\left(\mathrm{M}^{+}\right)$, $831.2\left(\mathrm{M}^{+}-\mathrm{CCPh}\right)$. Anal. Calcd for $\mathrm{C}_{59} \mathrm{H}_{44} \mathrm{OP}_{2} \mathrm{Ru}$ : C, 76.03, H, 4.76. Found: $C, 76.00 ; \mathrm{H}, 4.67$.

Preparation of $\left[\left(\eta^{5}-\mathrm{C}_{5} \mathrm{H}_{4} \mathrm{COCH}_{3}\right)(\mathrm{R}-\mathrm{B}\right.$ INAP $) \mathrm{Ru}=\mathrm{C}=$ $\mathrm{CHPh}_{\mathbf{C}} \mathrm{CF}_{3} \mathrm{COO}$ (4c). A tube was charged with $\mathbf{5 c}(25 \mathrm{mg}$, $0.027 \mathrm{mmol})$, and excess trifluoroacetic acid $\left(\mathrm{CF}_{3} \mathrm{COOH}\right)$ and chloroform-d were introduced into this tube. The ${ }^{1} \mathrm{H}$ and ${ }^{31} \mathrm{P}$ NMR spectra were collected. Complex $\mathbf{4 c}$ transformed to $\mathbf{3 c}$ ( $5 \%$ NMR yield) and other intractable products in $20 \mathrm{~min}$ at room temperature. No attempt was made to isolate $\mathbf{4 c}$ Spectroscopic data for $\mathbf{4 c}$ are as follows. ${ }^{1} \mathrm{H}$ NMR $\left(\mathrm{CDCl}_{3}\right)$ : $\delta$ 7.61-6.28 (m, 37H, Ph), 5.79, 5.48, 5.36, 4.97 (br, 4H, Cp), $4.34(\mathrm{~s}, 1 \mathrm{H}, \mathrm{C}=\mathrm{CH}(\mathrm{Ph})), 2.32\left(\mathrm{~s}, 3 \mathrm{H}, \mathrm{CH}_{3}\right) .31 \mathrm{P} \mathrm{NMR}\left(\mathrm{CDCl}_{3}\right)$ : $\delta 51.92(\mathrm{~d}, \mathrm{~J}$ p-p $=36.8 \mathrm{~Hz}), 35.73(\mathrm{~d}, \mathrm{~J} \mathrm{p}-\mathrm{p}=36.8 \mathrm{~Hz})$.

Preparation of $\left[\eta^{5}-\mathrm{C}_{5} \mathrm{H}_{4} \mathrm{C}\left(=\mathrm{CH}_{2}\right) \mathrm{CCPh}\right]($ dppe)RuCl (7d). Complex 6d $(105 \mathrm{mg}, 0.14 \mathrm{mmol})$ in $\mathrm{CH}_{2} \mathrm{Cl}_{2}$ was passed through an alumina-packed column. The yellow band was eluted with $\mathrm{CH}_{2} \mathrm{Cl}_{2}$. The solvent of this yellow band was removed under vacuum. The product was recrystallized from $\mathrm{CH}_{2} \mathrm{Cl}_{2} / \mathrm{n}$-hexane to give $7 \mathbf{d}(62 \mathrm{mg}, 60 \%)$. Spectroscopic data for $\mathbf{7 d}$ are as follows. ${ }^{1} \mathrm{H}$ NMR $\left(\mathrm{CDCl}_{3}\right): \delta 7.89-7.02(\mathrm{~m}, 25 \mathrm{H}$, $\mathrm{Ph}), 5.59\left(\mathrm{~s}, 1 \mathrm{H},=\mathrm{CH}_{2}\right), 5.46\left(\mathrm{~s}, 1 \mathrm{H},=\mathrm{CH}_{2}\right), 4.98(\mathrm{br}, 2 \mathrm{H}, \mathrm{Cp})$, 4.06 (br, 2H, Cp), 2.69-2.64 (m, 2H, $\left.\mathrm{PCH}_{2} \mathrm{CH}_{2} \mathrm{P}\right), 2.49-2.43$ $\left(\mathrm{m}, 2 \mathrm{H}, \mathrm{PCH}_{2} \mathrm{CH}_{2} \mathrm{P}\right) .{ }^{13} \mathrm{C} \mathrm{NMR}\left(\mathrm{CDCl}_{3}\right): \delta 141.8-123.9(\mathrm{~m}, \mathrm{Ph})$, $123.2\left(\mathrm{~s}, \mathrm{C}_{5} \mathrm{H}_{4} \mathrm{C}=\mathrm{CH}_{2}\right), 118.3\left(\mathrm{~s}, \mathrm{C}_{5} \mathrm{H}_{4} \mathrm{C}=\mathrm{CH}_{2}\right), 94.6,83.7,74.8$ (s, Cp), 89.2 (s, C $\equiv \mathrm{CPh}), 88.9$ ( $\mathrm{s}, \mathrm{C} \equiv \mathrm{CPh}), 27.7$ (t, $\mathrm{PCH}_{2} \mathrm{CH}_{2} \mathrm{P}$, $\left.J_{c-p}=22.3 \mathrm{~Hz}\right)$. ${ }^{31} \mathrm{p} \mathrm{NMR}\left(\mathrm{CDCl}_{3}\right): \delta 79.66(\mathrm{~s}) . \mathrm{MS}(\mathrm{FAB}):$ $\mathrm{m} / \mathrm{z} 726.2\left(\mathrm{M}^{+}\right), 691.2\left(\mathrm{M}^{+}-\mathrm{Cl}\right)$. Anal. Calcd for $\mathrm{C}_{41} \mathrm{H}_{35} \mathrm{P}_{2^{-}}$ RuCl: $\mathrm{C}, 67.81 ; \mathrm{H}, 4.86$. Found: $\mathrm{C}, 67.76 ; \mathrm{H}, 4.81$. Protonation of $\mathbf{7 d}$ in $\mathrm{CDCl}_{3}$ with excess $\mathrm{CF}_{3} \mathrm{COOH}$ gave a single product (8d). Spectroscopic data for $\mathbf{8 d}$ are as follows. ${ }^{1} \mathrm{H}$ NMR $\left(\mathrm{CDCl}_{3}\right): \delta 7.69-7.12(\mathrm{~m}, 25 \mathrm{H}, \mathrm{Ph}), 6.27,6.11,5.65,3.85(\mathrm{br}$ $4 \mathrm{H}, \mathrm{Cp}), 3.06-2.76\left(\mathrm{~m}, 4 \mathrm{H}, \mathrm{PCH}_{2} \mathrm{CH}_{2} \mathrm{P}\right), 1.26\left(\mathrm{~s}, 3 \mathrm{H}, \mathrm{CH}_{3}\right) .{ }^{31 \mathrm{P}}$ NMR $\left(\mathrm{CDCl}_{3}\right): \delta 86.46(\mathrm{~d}, \mathrm{~J} \mathrm{p}-\mathrm{p}=24.1 \mathrm{~Hz}), 73.93(\mathrm{~d}, \mathrm{~J}$ p-p $=$ $24.1 \mathrm{~Hz})$. FAB mass: $\mathrm{m} / \mathrm{z} 727.4\left(\mathrm{M}^{+}\right), 691.8\left(\mathrm{M}^{+}-\mathrm{Cl}\right)$.

X-ray Structure Determination of 3a and $6 \mathrm{~b}$. For $3 a$ a a single crystal of dimensions $0.20 \times 0.10 \times 0.10 \mathrm{~mm}^{3}$ was mounted on a glass fiber with epoxy. Data were collected at room temperature on a Siemens SMART CCD area detector system empl oying a $3 \mathrm{~kW}$ seal ed-tube $X$-ray source operating at $1.5 \mathrm{~kW}$. Data were collected using a narrow frame method. The total data collection yiel ded 11876 data after integration using SAINT. L aue symmetry revealed a orthorhombic crystal system, and unit cell parameters were determined from the least-squares refinement of three-dimensional centroids of 25 unique reflections. Data were corrected for absorption with the SADABS ${ }^{21}$ program. The space group was assigned as Pnma on the basis of systematic absences and intensity statistics using XPREP, and the structure was solved and refined using direct methods included in the SHELXTL ${ }^{22}$ package. For a Z value of 4 there is one independent molecule within the asymmetric unit. In the final model, non-hydrogen atoms were refined anisotropically, with hydrogen atoms included in idealized locations. The structure was refined to $R 1=0.0551$ and $w R 2=0.0798$ for all data $(R 1=0.0330$ and $w R 2=0.0702$ for $\mathrm{I}>2 \sigma(\mathrm{I})){ }^{23} \mathrm{~F}$ ractional coordinates and thermal parameters are given in the Supporting Information. The structure de termination of $\mathbf{6 b}$ was similarly carried out on a SMART CCD diffractometer. Relevant data for both crystals are given in Table 3.

Acknowledgment. Financial support from the $\mathrm{Na}$ tional Science Council of Tai wan is gratefully acknowledged.

Supporting Information Available: Details of the structural determinations for complex $\mathbf{3} \mathbf{a}$ and $\mathbf{6 b}$, including tables of crystal and intensity collection data, positional and anisotropic thermal parameters, and all of the bond distances and angles. This material is available free of charge via the Internet at http://pubs.acs.org.

\section{OM010893]}

(21) The SADABS program is based on the method of Blessing; see: Blessing, R. H. Acta Crystallogr., Sect. A 1995, 51, 33.

(22) SHELXTL: Structure Analysis Program, version 5.04; Siemens Industrial Automation Inc., Madison, WI, 1995

(23) $\mathrm{R} 1=\left(\Sigma|| \mathrm{F}_{\mathrm{o}}|-| \mathrm{F}_{\mathrm{c}} \|\right) / \Sigma\left|\mathrm{F}_{\mathrm{o}}\right| \cdot \mathrm{wR} 2=\left[\Sigma\left[\mathrm{w}\left(\mathrm{F}_{0}^{2}-\mathrm{F}_{c}^{2}\right)^{2}\right] / \Sigma\left[\mathrm{w}\left(\mathrm{F}_{0}^{2}\right)^{2}\right]\right]^{1 / 2}$ where $\mathrm{w}=1 /\left[\sigma^{2}\left(\mathrm{~F}_{0}^{2}\right)+(\mathrm{aP})^{2}+\mathrm{bP}\right]$ and $\mathrm{P}=\left[\left(\mathrm{Max} ; 0, \mathrm{~F}_{0}^{2}\right)+2 \mathrm{~F}^{2}\right] / 3$. GOF $=\left[\Sigma\left[w\left(F_{o}^{2}-F_{c}^{2}\right)^{2}\right] /(n-p)\right]^{1 / 2}$, where $n$ and $p$ denote the number of data and parameters, respectively. 